\title{
Textural characteristics and facies of sand-rich contourite depositional systems
}

BRACKENRIDGE, R.E. ", STOW, D.A.V.", HERNÁNDEZ-MOLINA, F.J.†, JONES, C. ${ }^{\ddagger}$, MENA, A. ${ }^{\dagger, \$}$ ALEJO, I. ${ }^{\S}$, DUCASSOU, E. ${ }^{\natural}$, LLAVE, E. ${ }^{* *}$, ERCILLA, G. ${ }^{\dagger \dagger}$,

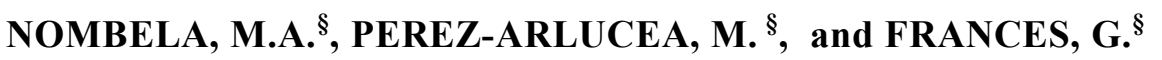

\footnotetext{
* School of Energy, Geoscience, Infrastructure and Society, Heriot-Watt University, Edinburgh, EH144AS, United Kingdom (E-mail: R.Brackenridge@hw.ac.uk)

${ }^{\dagger}$ Dept. Earth Sciences, Royal Holloway University, London, TW20 OEX Egham, Surrey, United Kingdom

${ }^{\ddagger}$ School of Geography and the Environment, Oxford University, Oxford, OX1 3QY, United Kingdom

$\S$ Dpto. de Xeociencias Mariñas e O.T., Univ. Vigo, E-36310 Vigo (Pontevedra), Spain

" Université de Bordeaux, UMR CNRS 5805 EPOC, Talence cedex, France

** Instituto Geológico y Minero de España (IGME), Rios Rosas 23, 28003 Madrid, Spain

${ }^{\dagger \dagger}$ Centro de Investigaciones Marinas y Ambientales (CMIMA-CSIC), Paseo Marítimo Barceloneta, 37-49, 08003 Barcelona, Spain
}

\section{Associate Editor - Mariano Marzo}

Short Title - Sand-rich contourite systems

\begin{abstract}
This work presents a detailed study of CONTOURIBER and Integrated Ocean Drilling Program 339 sediment data targeting sand-rich contourites in the Eastern Gulf of Cadiz. All of the collected sediments are interpreted as contourites (deposited or reworked by bottom currents) on the basis of oceanographic setting, seismic and morphometric features and facies characteristics. A variety of sandy and associated facies are found across the study area including: (i) bioturbated muddy contourites; (ii) mottled silty contourites; (iii) very fine mottled and fine-grained bioturbated sandy contourites; (iv) massive and laminated sandy contourites; and (v) coarse sandy/gravel contourites. The thickest sands occur within contourite channels and there is a marked reduction in sand content laterally away from channels. Complementary to the facies descriptions, grain-size analysis of 675 samples reveal distinctive trends in textural properties linked to depositional processes under the action of bottom currents. The finest muddy contourites $(<20 \mu \mathrm{m})$ show normal grain-size

This is an Accepted Article that has been peer-reviewed and approved for publication in the Sedimentology, but has yet to undergo copy-editing and proof correction. Please cite this article as an "Accepted Article"; doi: 10.1111/sed.12463
\end{abstract}


distributions, poor to very poor sorting, and zero or low skewness. These are deposited by settling from weak bottom currents with a fine suspension load. Muddy to fine sandy contourites (20 to 200 $\mu \mathrm{m})$ trend towards better sorting and initially finer and then coarser skew. These are typical depositional trends for contourites. As current velocity and carrying capacity increase, more of the finest fraction remains in suspension and bedload transport becomes more important. Clean sandy contourites $(>200 \mu \mathrm{m})$ are better sorted. They result from the action of dominant bedload transport and winnowing at high current speeds. The results highlight the importance of bottom current velocity, sediment supply and bioturbational mixing in controlling contourite facies. Despite growing interest in their hydrocarbon exploration potential, contourite sands have remained poorly understood. This research therefore has important implications for developing current understanding of these deposits and aiding the correct interpretation of deep marine sands and depositional processes.

Keywords Contourites, deep-water sands, grain size, Gulf of Cadiz, sediment facies model.

\section{INTRODUCTION}

Contourites are those sediments deposited or substantially reworked by bottom currents (Stow et al., 2002). In areas with long-term deposition, they can construct large mounded drifts (contourite drifts) in a variety of shapes and sizes, which may be elongated up to several hundreds of kilometres along the continental margin (Rebesco et al. 2014; Esentia et al. 2017). The characteristics of the finegrained sediments collected from these mounded drifts are now well-constrained thanks to early facies and textural studies (Stow \& Lovell, 1979; Gonthier et al., 1984; Stow \& Piper, 1984). More recently, the capability of bottom currents to deposit significant accumulations of sand-rich facies has been recognized. The characteristics of these sandy contourites are still poorly understood and, therefore, can be difficult to distinguish from other deep water sands, such as turbidites.

The eastern Gulf of Cadiz (Fig. 1) contains one of the largest modern sand-rich contourite depositional systems in the world. It covers an estimated area of $4000 \mathrm{~km}^{2}$ and industry boreholes suggest that there is over $800 \mathrm{~m}$ of sand-rich contourite section (Buitrago et al. 2001; Antich et al. 2005). It therefore provides an ideal location for the study of contourite sands, their characteristics and controlling factors. These contourite sands form part of a much larger contourite depositional system in the Gulf of Cadiz (e.g. Llave et al., 2007, fig. 1; Hernández-Molina et al., 2016), for which a huge database exists (surface and subsurface). This database has been expanded with targeted data 
acquisition over the sand-dominated region in the east of the Gulf of Cadiz, which is the focus of this study.

This sediment dataset is one of the largest for any sand-dominated contourite system acquired to date. This study develops: (i) the key features of the contourite facies recovered from the eastern Gulf of Cadiz; (ii) their textural characteristics and key insights on contourite depositional processes; and (iii) a new sedimentary facies model for contourite sands. Better characterization of these deposits in modern settings will aid their identification in the subsurface and allow their reservoir and hydrocarbon play potential to be evaluated (Viana \& Rebesco 2007).

\section{CONTOURITES: CURRENT KNOWLEDGE}

Contourites are defined as any sediment deposited or substantially reworked by the persistent action of bottom currents (Stow et al., 2002; Rebesco et al., 2014). These bottom currents are capable of eroding, transporting and depositing sediments along the sea floor (Rebesco \& Camerlenghi, 2008). Thermohaline-driven bottom currents, such as those encountered in this study, generally operate most effectively in deep water (i.e. off-shelf). They may also be present on the continental shelf, where they compete with other processes, such as wind- or tidal-driven circulation, which may have an even greater effect on sediment deposition. Thermohaline-driven currents generally exhibit persistent along-slope flow (following the local bathymetry) but can vary in direction and velocity due to the influence of other oceanographic processes (e.g. Shanmugam, 2012, 2013; Rebesco et al., 2014). Such processes form contourite facies in deep-water settings (Shanmugam, 2012; Stow et al., 2013a,b), and represent an entirely different deep-water deposit from turbidite and pelagic sediments (Viana, 2008; Stow et al., 2013b).

Fine-grained contourite facies (muds, silts and muddy sands) have been well-studied in previous works and their principal features are fairly well-constrained (Stow \& Lovell, 1979; Gonthier et al., 1984; Stow \& Piper, 1984; Alonso et al., 2016). They are distinguished from other fine-grained deposits (pelagic and turbiditic) on account of their bi-gradational sequences, distinctive uniform composition and textural characteristics, and their absence of primary sedimentary structures due to intense bioturbation. The now widely-recognized standard contourite facies model is based on an extensive compilation of data from modern and sub-recent sediments worldwide. The elements of this model, first developed by Stow (1977, 1982), were combined into the contourite sequence by Gonthier et al. (1984), Stow \& Piper (1984) and Faugères et al. (1984), with the later addition of the 
C1 to C5 notation (Stow et al., 2002; Stow \& Faugères, 2008). The bi-gradational grading represents continuous sedimentation over an interval of several millennia and has been interpreted to be the result of the interaction of three independent controls (Stow et al. 1986): (i) fluctuation in mean bottom current velocity, with the coarsest division, C3, representing the maximum velocity; (ii) variation in lateral sediment supply, principally from turbidity currents; and (iii) variation in vertical sediment supply from primary biogenic productivity in surface waters. The complete contourite sequence is not always present, but is typically found as partial contourite sequences (Stow \& Faugères, 2008).

Contourite sands, especially the clean medium and coarse sands, are much less well-known and are also, therefore, much more difficult to distinguish from other deep-water sands. Typically, most contourite sands have been assigned to the C3 division of the standard contourite facies model, although Stow \& Faugères (2008) did recognize the need for a different facies model specifically for sand-rich contourites. Viana et al. (1998) had previously described 'bottom-current controlled sand deposits' from a variety of deep-water environments, but where they were uncertain of classifying the sediments as contourites. More recent work has elucidated the role of other processes, such as winddriven currents, internal tides, internal waves, benthic storms and tsunami-generated bottom currents in depositing very similar sandy facies (Rebesco et al., 2014), as well as those deposited by mixed alongslope and downslope process interaction.

Stanley (1993) introduced the concept of bottom-current winnowed turbidite deposits. These occur where a downslope turbidite channel-levée system is formed under a bottom current. The current can pirate fines from the turbidity current overspill plume and redistribute them alongslope (Shanmugam, 2006). Evidence for interaction may also be seen at a facies-scale as modified turbidites (Stanley, 1993; Mulder et al., 2008). Examples of such deposits have been interpreted from the Columbia Channel offshore Brazil (Faugères et al., 2002) and Kazusa Forearc, Japan (Ito, 1996). Mixed downslope-alongslope and systems influenced by internal tides have been described in several cases (Shanmugam et al., 1995; Shanmugam, 2006, 2012; Youbin et al., 2008, 2011) although there is still considerable debate over what features accurately reflect this process interaction. 
At higher bottom current velocities, the complete removal and redistribution of incoming downslope sediment, as well as widespread erosion, may occur as is seen along the Pliocene of the Algarve margin of the Gulf of Cadiz (Brackenridge et al., 2013a). The pirated and eroded sediment will be re-deposited elsewhere in the basin where the transport capacity of the current is diminished. According to most accepted definitions, these are true contourites. No comprehensive sediment facies and textural study has been completed to date in a setting that is contourite dominated such as the Gulf of Cadiz.

\section{GULF OF CADIZ: GEOLOGICAL AND OCEANOGRAPHIC SETTING}

\section{Geological setting}

The Gulf of Cadiz has had a complex and dynamic tectonic history as a result of its location on the boundary between the African and Eurasian continental plates. Three key events have been identified as crucial geological factors responsible for the modern set-up of the margin (Maldonado et al., 1999; Hernández-Molina et al., 2006): (i) Late Mesozoic passive margin development related to rifting, sea floor spreading and the opening of the Tethys and Atlantic Oceans; (ii) Cenozoic convergence of the African and Eurasian plates in a north-south direction; and (iii) foredeep formation relating to BeticRifean orogenesis east of the Gulf of Cadiz. Today, a compressional tectonic regime coupled with oblique WNW-ESE motion gives an apparently slowing rate of convergence and a move to tectonic stability (Rosenbaum et al., 2002).

The continental margin of the Gulf of Cadiz is broadly arcuate, ca $350 \mathrm{~km}$ long, and runs from the Strait of Gibraltar to the south-western tip of Portugal (Cape St Vincent; Fig. 1). The shelf break is at a water depth of 120 to $140 \mathrm{~m}$ and the continental slope joins the abyssal plain at depths of over 4300 $\mathrm{m}$. Morphological features of the continental slope include both downslope and alongslope depositional and erosional elements (Hernández-Molina et al., 2006; Medialdea et al., 2009). The emplacement of an unstable allocthonous unit in the Miocene has led to intense mud-diapirism and halokinesis along the margin. The resulting mud volcanoes, diapiric ridges and adjacent depocentres modify the modern day oceanic conditions (Somoza et al., 2003; Hernández-Molina et al., 2006; Llave et al., 2007; Tasianas 2010). 


\section{Oceanographic setting and impact on sedimentary processes}

The Gulf of Cadiz is dominated by the water exchange between the Atlantic Ocean and Mediterranean Sea. The Strait of Gibraltar allows for the exchange between the warm saline Mediterranean Outflow Water (MOW) and the overlying Atlantic Inflow Water (AIW) (Howe, 1982; Baringer \& Price, 1999; Lobo et al., 2000; Ambar et al., 2002; Cabecadas et al., 2002; Garcia-Lafuente et al., 2006; Llave et al., 2007). The MOW is composed of a mixture of water masses sourced from the Mediterranean Basin (Millot, 2009). It accelerates through the narrow Strait of Gibraltar - locally reaching velocities up to $300 \mathrm{~cm} \mathrm{sec}^{-1}$ (Ambar \& Howe, 1979; Mulder et al., 2003) as it cascades down the shallow sill within the Strait. It forms a turbulent density-driven flow before veering towards the north-west along the mid-continental slope of the Gulf of Cadiz in multiple distinct cores of differing properties (Fig. 1). Density-driven descent (Legg et al., 2009) and mixing with overlying Atlantic waters results in decreasing salinity along the margin from south-east to north-west (Baringer \& Price, 1997). Eventually the MOW leaves the sea bed and reaches a neutral buoyancy at a depth of 1200 to $1400 \mathrm{~m}$ offshore of Cape St Vincent, where it begins to raft above the North Atlantic Deep Water (Zenk, 1975; Ambar et al., 1999).

Mediterranean Outflow Water-influenced contourite sedimentation in the Gulf of Cadiz is estimated to have begun in the early Pliocene (van der Schee et al., 2016). Hernández-Molina et al. (2003, 2006) and Llave et al. (2007) have identified five distinct 'morphological sectors' (Fig. 1) that have developed in direct response to the broadly diminishing bottom current velocities from the proximal sector close to the Strait of Gibraltar in the east, to the canyons sector in the west where bottom current velocities are so reduced that downslope processes begin to dominate. Sector 1, the most proximal to the Strait of Gibraltar, is the area of interest in this study on account of the abundant contourite sands deposited there.

This study uses the terminology and mapped extent of morphological features as described in detail by (Hernández-Molina et al., 2014). Proximal to the Strait of Gibraltar, the turbulent cascade of the MOW over the Strait of Gibraltar (Legg et al., 2009) has resulted in two large and deep erosional channels with areas of rocky outcrop (Hernández-Molina et al., 2014) (Fig. 2). These channels open onto broad erosional terraces (over $2000 \mathrm{~km}^{2}$ in area) that form a major abraded surface between 500 $\mathrm{m}$ and $800 \mathrm{~m}$ water depth. This surface is dominated by erosional processes; seismic reflections show truncation and aligned features that are V-shaped in cross-section, interpreted as erosive scours or giant furrows (Hernández-Molina et al., 2006, fig. 9). Erosive features pass to gravel and sand lag deposits and subsequently give way to sand ribbon and wave deposits. Plastered drifts are found along 
the upper slope, and a mounded drift has developed at the north-western limit of the erosional terraces (Fig. 2) (Hernández-Molina et al., 2014, fig. 2C). Moving downslope, a large contourite drift separates the erosional terraces from the Lower Continental Slope (Mulder et al., 2003; HernándezMolina et al., 2014). The lower slope consists of wave fields, channels and depositional lobes (Habgood et al., 2003). This distribution of features represents the reduction of MOW velocity (and thus sediment transport capacity) moving away from the Strait of Gibraltar to the north-west as well as laterally away from the main MOW flow (Mulder et al., 2003; Llave et al., 2006, 2007).

Some work has been carried out on the adjacent shallow water sediments on the continental shelf (Nelson et al., 1993, 1999; Maldonado et al., 2003; Lobo et al., 2010), the adjacent channel and sediment waves sectors (Akhmetzhanov et al., 2007; Hanquiez et al., 2007), as well as within the Strait of Gibraltar (Kelling \& Stanley, 1972; Esteras et al., 2000). Focused studies on the region most proximal to the Strait of Gibraltar, however, remain limited to a very few. These include: two industry studies (Buitrago et al., 2001; Antich et al., 2005); some superficial and remotely-sensed studies (Kenyon \& Belderson, 1973; Habgood et al., 2003; Mulder et al., 2003), and some recent publications relating to the data used in this study (Alejo et al., 2012; Brackenridge et al., 2013b; HernándezMolina et al., 2014).

\section{DATA AND METHODOLOGY}

\section{Data}

This study utilizes core data of differing vintages (Table 1; Fig. 2). Three piston cores, two trigger cores and one box core were acquired on the Scientific Cruise CONTOURIBER-1 on the $R / V$ Sarmiento de Gamboa, October 2010. The three $12 \mathrm{~cm}$ diameter piston cores (PC06, PC04 and PC08) were divided into sections approximately $1 \mathrm{~m}$ in length for ease of transportation. The box core (BC05) was sub-cored and sliced at a resolution of $1 \mathrm{~cm}$ for sampling. In total, ca $16 \mathrm{~m}$ of gravity cores were retrieved.

Six sites were drilled across the Gulf of Cadiz during Integrated Ocean Drilling Program (IODP) Expedition 339, which sailed from 16 November 2011 to 16 January 2012, and in total $5.5 \mathrm{~km}$ of cores were recovered (Expedition 339 Scientists, 2012; Stow et al., 2013a). These sites targeted a variety of depositional environments across the Gulf of Cadiz, and the key site of interest in this study is U1388, located in the east (Fig. 2). This site penetrated $253 \mathrm{~m}$ and recovered a total of $121 \mathrm{~m}$ of 
core (Expedition 339 Scientists, 2012). This study focuses on the top $6 \mathrm{~m}$ of core U1388, which was logged in detail and sampled at the MARUM Core Repository, University of Bremen. A detailed morpho-sedimentary study of the area where the cores were collected has been carried out by Hernández-Molina et al. (2014). The defined erosional and depositional features described in that study are used to describe the location and depositional environment of the cores studied here.

\section{Core logging}

Visual description was carried out on all cores (Table 1). This included conventional sediment logging, core photography and computed tomography (CT) imaging where available. The top $6 \mathrm{~m}$ of IODP core U1388 was completed using visual core description. The three piston cores and their respective trigger cores collected on the CONTOURIBER-1 cruise (PC04, PC06 and PC08) were selected for high-resolution photography immediately after slabbing using an Avaatech XRF Core Scanner (Avaatech BV, Alkmaar, The Netherlands) located at the Universitat de Barcelona Faculty of Geology. In addition, CT-scanning was carried out at the Facultade de Veteranaria at the Universidad de Santiago de Compostela, Lugo (Spain) (Fig. 3) following the procedure published by Mena et al. (2015). Each core was scanned using a high-resolution Hitachi ECLOS medical scanner (Hitachi, Tokyo, Japan). The data was displayed in the freeware MRIcro (Rorden \& Brett, 2005) where it can be manipulated in terms of colour, contrast and slice location in order to enhance any density contrasts within the sediment. Figure 3 shows the entire CT-scanned core using the 'Rainramp' colour bar with a contrast of 800 and a brightness of 1130 in order to optimize the density contrasts within the cores. The resulting image has a resolution of $0.2 \times 0.2 \times 0.625 \mathrm{~mm}^{3}$. This hugely improves the ability to $\log$ broad grain-size trends, erosional boundaries and sedimentary features. In particular, burrows are more clearly seen, an important diagnostic criterion of contourite facies. Visual core description was backed up by smear slide analysis (sampling locations indicated in Fig. 3).

\section{Textural analysis}

The CONTOURIBER piston and trigger cores were sampled at a regular $2 \mathrm{~cm}$ resolution. An additional 33 samples were collected from IODP core U1388 (Table 1; Fig. 3). A total of 675 samples were analysed for grain-size at the University of Bordeaux using laser counting methods on a Malvern Particle Size Analyser machine (Malvern Instruments Limited, Malvern, UK) using standard procedures (Lewis \& McConchie, 1994). Laser counters measure grain sizes from $0.05 \mu \mathrm{m}$ to $700 \mu \mathrm{m}$ - or clay up to medium/coarse sand. Since BC05 showed coarse to very coarse sediment content, the 23 samples from the box core were analysed using sieving methods at Heriot-Watt University. 
The standard procedure for grain-size analysis in laser counters was used as outlined by McCave et al. (1986), Cooper (1998) and Martins (2003). Additional grain-size sieving methods were used on samples too coarse for the laser counters (Lewis \& McConchie, 1994). Distributions are given in a geometric (volume) scaling rather than arithmetic (number) scale to ensure that there is equal emphasis on changes in clay, silt and sand content in the histogram (Blott \& Pye, 2001). All analysis was carried out in the software GRADISTAT (Blott \& Pye, 2001) using the geometric graphical method as laid out by Folk \& Ward (1957) to ensure that each set of analysis can be directly compared to others in the study. Key statistical measures include: mean, sorting (standard deviation), skewness and kurtosis. The formulae used for these measurements and the cut-off values for defining the sorting, skewness and kurtosis are outlined in Blott \& Pye (2001). Cumulative frequency curves were created to clearly visualize differences in distribution. After calculation of the essential statistics, data were compared using cross-plots (Folk, 1964; Martins, 2003). The scale and sediment classes as defined by Wentworth (1922) were used.

\section{Sediment dating}

In total, 13 samples have been dated using radiocarbon methods: three each from PC06, PC08 and U1388, and four from PC04 (Table 2; Fig. 3). Coarse-grained BC05 was thought to consist of large amounts of reworked material, therefore being unsuitable to allow for accurate dating and was excluded from the analysis. Planktonic foraminiferal species of Globigerina bulloides and Globigerinoides ruber were targeted for the dating. This was carried out at the Scottish Universities Environmental Research Centre (SUERC) Radiocarbon Dating Laboratory in the UK and the Laboratoire de Mesure du Carbone 14 (France) using accelerator mass spectrometry (AMS) methods. All radiocarbon ages were calibrated using the University of Oxford Radiocarbon Accelerator Unit Calibration Program OxCal4 (using the Marine13 calibration curve).

\section{RESULTS}

\section{Sediment facies and facies sequences}

Core logging

Logging of the seven cores demonstrates varying facies characteristics across each core site (Fig. 3). Most proximally to the Strait of Gibraltar, BC05 is located within the Southern Channel that contains the Mediterranean Outflow as it sweeps around the Gulf of Cadiz continental slope (Fig. 2). The This article is protected by copyright. All rights reserved. 
sediments collected from this box core are the coarsest in the study, ranging from medium to very coarse sand. Smear slide analysis reveals a mixed composition of predominantly quartz with bioclastic material. The largest grain sizes are made up of shelly debris. There is evidence of lamination, but bioturbation is not seen.

Adjacent to the Southern Channel, PC04 was collected from a mounded contourite drift at $658 \mathrm{~m}$ water depth. Facies range from silt to fine sand, and seven units are identified separated by both abrupt and gradational boundaries (Fig. 3). A thin $30 \mathrm{~cm}$ tan-brown unit tops the succession (unit 1). On analysis of the associated trigger core PCO4TG, this unit reaches $35 \mathrm{~cm}$ in thickness (Fig. 3). Unit 2 is the thickest at 2.53 m thick. It is composed of very poorly sorted sandy mud. Within this unit there are multiple gradational changes towards sandy silts and occasional fine sand lenses. Subtle lamination is seen in the upper $20 \mathrm{~cm}$, but in general the unit is highly bioturbated and mottled in appearance. The sediment is of mixed composition with a significant foraminifera portion, in addition to quartz and other terrigenous clasts. The underlying units 3, 4 and 5 are much thinner: $0.25 \mathrm{~m}, 0.48 \mathrm{~m}$ and $1.1 \mathrm{~m}$ respectively. Unit 3 appears to down cut into the underlying unit and is made up of highly bioturbated fine sand. The underlying unit shows a subtle fining upward sequence of bioturbated sandy silts and muds. An abrupt surface separates this unit from the underlying unit 5 which has a broadly coarsening upward trend consisting of fine sandy muds with sections of higher portions of sand. There is subtle cross-lamination in this unit with larger scale bioturbation in the sandier sections (Fig. 3). Unit 6 is separated from the overlying unit by a sharp surface and consists of silty mud grading upward to a very poorly sorted silty fine sand. Burrows are seen penetrating downwards from the upper boundary of this unit and large (centimetre-scale) burrows are observed in the sandier section (Fig. 3). There is poor core recovery within this sandy section, but it appears to be over $1 \mathrm{~m}$ in thickness with reverse grading. Muddy silt at the base of the unit is heavily bioturbated and mottled in appearance. The lowermost unit 7 is a bioturbated silty sand and has a similar composition to the overlying units with significant quartz and nannofossil portions. In the sandy sections, foraminifera are relatively lacking, and in the lower sandy section, quartz grains are iron-stained.

Collected from the same mounded drift, PC08 is located more distally to the north-west, and deeper on the continental slope than PC04, at 961 m water depth (Fig. 2). Despite being the finestgrained of the sediment cores, PC08, still shows six distinct sedimentary units separated by sharp boundaries (Fig. 3). Unit 1 is only $6 \mathrm{~cm}$ thick in PC08, but reaches $43 \mathrm{~cm}$ in the trigger core PC08TG This article is protected by copyright. All rights reserved. 
(Fig. 3). It is composed of muddy silt with a dominantly bioclastic composition (nannofossils, foraminifera, siliceous sponge fragments and bryzoa). As with unit 1 in PCO4, it has a distinct tan colour in core and is highly bioturbated. This is separated from the underlying unit 2 by an abrupt (but with no evidence for being erosive) boundary. Unit 2 is approximately $2.25 \mathrm{~m}$ thick and is a poorly sorted muddy silt with localized cleaner silts. There is some minor coarsening upward in the top $20 \mathrm{~cm}$ of the unit. It is of mixed silici-bioclastic composition with notable quartz, foraminifera and nannofossil (coccolith) portions. Units 3 and 4 show coarser sediment accumulation with very poorly to poorly sorted muddy sands. The boundary between units 3 and 4 appears abrupt and down cutting, with unit 4 being topped by muddy sand, and grading down the core back to muddy silt. Quartz tends to make up the coarsest portion of the sediment and is commonly iron-stained. At the base of unit 4 at $5.1 \mathrm{~m}$ below sea floor (bsf), another abrupt grain-size change is identified, with the underlying unit 5 comprising a coarsening upward succession from muddy silt to muddy fine sand. The lowermost unit 6 is also the coarsest in PC08. It is a very poorly sorted muddy fine sand of mixed composition separated from the overlying unit 5 by a sharp boundary. The entire core is very heavily bioturbated with small-scale burrows (Fig. 3).

Core PC06 is located on the upper continental slope at $490 \mathrm{~m}$ water depth. It is adjacent to the northern channel defined by Hernández-Molina et al. (2014) and collected from a plastered contourite drift (Fig. 2). It consists of three sedimentary units that are separated by sharp contacts (Fig. 3). Unit 1 is $40 \mathrm{~cm}$ thick and consists of moderately sorted fine sand. Compositionally, this unit is dominated by terrigenous sediment (quartz and feldspars), with a minor component of shell fragments and foraminifera. The unit is devoid of sedimentary structures and only rare large-scale bioturbation in observed. There is some evidence of fluidized deformation. This unit differs greatly from the underlying unit 2 - a very poorly-sorted muddy sand. Unit 2 maintains a mixed composition, but has a much larger bioclastic component, mainly siliceous sponge fragments and foraminifera. It is heavily bioturbated and shows complex grading patterns. The underlying unit 3 shows an increase in sand portion. The unit does not show any evidence for fluidization as is observed in unit 1 and large-scale bioturbation can be seen. However, the unit is largely devoid of primary structures.

The final core to be logged, the upper ca $6 \mathrm{~m}$ of Core U1388, is located downslope of PC06 at 663 $\mathrm{m}$ water depth, in the northern channel (Hernández-Molina et al. 2014, fig. 2C) (Fig. 2). The upper $3.5 \mathrm{~m}$ of this core consists of moderately sorted medium sands (Fig. 3). This uppermost section is divided into two amalgamated sands units separated by a significant surface at $1.4 \mathrm{mbsf}$. The upper

This article is protected by copyright. All rights reserved. 
unit is structureless with only rare large-scale bioturbation observed. There is no evidence for fluid deformation. The underlying sand shows more common large-scale burrows and coarser sand lenses. Poor recovery rates have led to a missing section directly below the sandy facies, below which a further three units have been identified (Fig. 3). These units have very different characteristics from the upper section of the core. The grain size is much more varied, with muddy, silty and sandy layers. Muddier sections are heavily bioturbated with small (millimetre-scale) bioturbation and mottled textures. Siltier and sandier layers show weak lamination. Boundaries are sharp or gradational.

\section{Sediment texture}

\section{Grain-size statistics}

The mean grain-size and sorting parameters for each core are plotted against depth in Fig. 4. The results show that cores $\mathrm{PC} 04$ and $\mathrm{PC} 08$, together with their respective trigger cores, are characterized by mainly clay and silt-sized sediment, punctuated by thinner intervals of coarser silts and fine sands. Cores BC05, PC06 and U1388 by contrast, are much more sand rich, with some samples having mean grain sizes in the coarse to very coarse sand range. Sorting statistics are varied, with standard deviations ranging from 1.8 to 5.4 phi units, which corresponds to between moderately sorted and very poorly sorted sediment. The topmost bed of PC06 (fine sand) and the upper parts of U1388 (fine-medium sand) show the best degree of sorting - with $\sigma$ values of 1.2 to 1.5 , or moderately to moderately-well sorted. BC05 also shows better sorting than most of the other cores. The remainder of PC06 rarely shows mean grain sizes smaller than coarse silt $(<31.0 \mu \mathrm{m})$ or medium silt $(<15.6 \mu \mathrm{m})$. The same can be said for the lowermost metre of PC04. Therefore, the fine silt $(<15.6 \mu \mathrm{m})$ and muddy $(<3.9 \mu \mathrm{m})$ sections show a very different pattern of sorting compared to the coarser sections in PC06/U1388 and the lowermost metre of PC04. The link between grain size and sorting is evidently not straightforward, and appears to differ between the more mud-rich and more sand-rich facies (Fig. 4).

The cross-plot of mean grain size and sorting (Fig. 5A) is quite revealing. Samples taken from PC08, the most mud-rich of the piston cores, show a decrease in sediment sorting with increasing mean grain size. The same is true for the mud-rich upper part of PC04. However, for PC06 and the lower more mixed and silt/sand-rich part of PC04, there is a clear trend that shows an increase in sediment sorting (i.e. towards better sorting) with increasing grain size. The coarsest of the sediment cores, $\mathrm{U} 1388$ and $\mathrm{BC} 05$ show a return towards poorer sorting (Fig. 5A).

This article is protected by copyright. All rights reserved. 
The cross-plot of mean grain size against skewness data is shown in Fig. 5B. Medium to coarse sands show a coarse to very coarse skew. Fine to very fine sands and silts are generally fine and very fine skewed, reaching a maximum fine skew (-0.7) for a grain size of 50 to $60 \mu \mathrm{m}$. The finest silts and clays are more normally distributed. The cross-plot of skewness against sorting, shown in Fig. 6A is coded for grain size rather than core site. This further emphasizes the separation in characteristic trend (and hence behaviour) of the medium to coarse sands, from the fine to very fine sands and from the silts to clays.

Figure 5C shows the relationship between mean grain size and kurtosis. The kurtosis values measured from the sediment distributions range from 0.7 (platykurtic) to 2.6 (very leptokurtic). There is a distinctive trend from platykurtic to very leptokurtic (i.e. increasing peakedness of the distribution) as the grain size increases from coarse silt to fine sand. Fine sands show the highest concentration of data around the mean whereas both the finer and coarser sediments show a broader (platykurtic) spread. Kurtosis has also been plotted against skewness and shows several interesting but complex relationships, this time plotted for grain size rather than core site (Fig. 6B). The different grain-size classes show somewhat different trends. Specifically, a concentration of fine sand data points plots quite separately from the rest the data. The majority of the data plots along two or three straight to curved trend lines (Fig. 6B).

\section{Cumulative frequency curves}

Figure 7 shows cumulative frequency curves for all the samples separated into different groups according to their mean grain size for convenience of observation. The distribution curves are significantly different depending on the mean grain size. The fine silts and medium silts show smooth S-shaped curves with a small top and base. From coarse silt to fine sand, there is a diminution of the base curve and increase in size of the upper curve. The medium to coarse sands show straight to slightly kinked distribution with base and top curves mostly absent.

\section{Sediment dating}

Table 2 shows the results from the radiocarbon dating. The range of error bars on these dates for ages less than 35000 years BP are low (71 to 142 years), whereas those up to 45000 years BP range up to 1916 years (Table 2). The results show that all sediments are late Quaternary to Holocene in age and 
reach a maximum calibrated age of 47,983 $\pm 1400 \mathrm{BP}$, which is dated at latest Pleistocene (Tarantian). Figure 8 illustrates that depositional rates are very different between the core sites. Muddy facies show the slowest rates of accumulation $(<15 \mathrm{~cm} / \mathrm{ka})$ and sandy facies show the highest rates $(>30$ $\mathrm{cm} / \mathrm{ka})$. Especially high rates of accumulation are observed in the upper section of core U1388 (>100 $\mathrm{cm} / \mathrm{ka}$ ) and in the lower section of PC04 (>198 cm/ka).

\section{INTERPRETATION}

\section{Sediment facies}

A variety of facies from fine muds through to coarse-grained sands have been interpreted in the logged cores (Figs 3 and 9). Based on the CT-scanning and visual logging, the different facies have been grouped into five principal types (Figs 9 and 10): (i) Facies A - bioturbated muddy facies; (ii) Facies B - mottled silty facies; (iii) Facies C - very fine mottled to fine-grained bioturbated sandy facies; (iv) Facies D - massive and laminated medium-grained sandy facies; and (v) Facies E coarse-grained sandy and gravel facies. Key features of each of the facies are outlined below.

Facies A - bioturbated muddy facies. Muddy deposits are typically $100 \%$ reworked by bioturbation (Fig. 10A). The core surface appears massive with no sedimentary structures seen to have been preserved. Very small-scale burrows such as Chondrites can be distinguished in CT-images on the order of some $\mathrm{mm}$ in length and diameter. They are chaotically orientated and cross-cutting. Some longer $(2$ to $10 \mathrm{~cm}$ ) vertical burrows are also seen, particularly where sand fill causes high-density contrasts with surrounding mud. Organic material and rare shell debris are also seen in the core. Bioturbated muddy facies become thicker and more dominant distally from the Strait of Gibraltar and laterally away from the main MOW core (Fig. 9; PC08).

Facies $B$ - mottled silty facies. The silty facies occur as indistinct beds (or units), typically grading into muds or fine sands. They also form thin discrete layers and lenses within an otherwise mud-rich facies. Highly bioturbated, fine silts commonly show a mottled appearance at the core surface and an absence of primary structures (Fig. 10B). Small-scale burrows are common, but CT-imaging also shows examples of probable Thalassinoides and Planolites trace fossils that form spherical and elongate mud-filled burrows up to $10 \mathrm{~cm}$ in length. There are also various large-scale (up to centimetre diameter) trace fossils that run horizontally across the sediment core (Zoophycos?). Where 
interbedded with muds or sandy facies, larger burrows can be observed clearly due to infill from adjacent facies.

Facies $C$-very fine mottled to fine-grained bioturbated sandy facies. Fine-grained sands are found as discrete millimetre-scale layers and lenses within other facies, and as thicker units (reaching $>2 \mathrm{~m}$ in core U1388). Very fine-grained sands are commonly highly bioturbated, and can therefore appear mottled at the core surface (Fig. 10C). They are also characterized by larger-scale burrows (up to $1 \mathrm{~cm}$ in diameter) that form spherical and elongate mud-filled trace fossils such as Thalassinoides and Planolites up to $10 \mathrm{~cm}$ in length. These are particularly visible in CT images (Fig. 10C).

Facies D - massive and laminated medium-grained sandy facies. Where the sand content is high (greater than $70 \%$ ) there is a marked reduction in evidence of bioturbation. Very large-scale (greater than $1 \mathrm{~cm}$ in diameter) burrows may be preserved, together with some rare hints of lamination (Fig. 10D). Most commonly, however, the medium-grained sand facies are massive (Fig. 10D). In some recovered sections, unconsolidated sands show fluid deformation related to the acquisition process (for example, PC06 unit 1). Other units show no evidence of such deformation (for example, PC06 unit 1; U1388 unit 1) and the structureless nature of the sands is interpreted to be depositional. Coarser sandy and gravel lags and lenses are also common. They tend to show gradational bed boundaries, grading to fine sand. There are also abrupt erosive contacts, particularly at the upper boundary.

Facies E - coarse-grained sandy and gravel facies. Coarse-grained sand facies are most commonly found in thin lag layers with erosive basal boundaries. Where thicker $(>10 \mathrm{~cm})$ accumulations are recovered, there is bi-gradational grading and evidence of lamination. The coarse sands have a large bioclastic component consisting of broken shelly material (Fig. 10E).

Facies interpretation. Following the three-scale diagnostic scheme proposed for the recognition of contourites by Lovell \& Stow (1981), the seismic characteristics of contourites (Faugères et al., 1999; Nielsen et al., 2008; Rebesco et al., 2014) and the most generally accepted criteria for facies identification (Stow et al., 2002; Stow and Faugères, 2008), it can be confidently concluded that all of the sediments studied here are contourites. For the most part, Facies A to E can be associated with the standard contourite C1 to C5 terminology of Stow et al. (2002). Facies A - bioturbated muddy facies represents the lowest energy depositional environment and can be assigned to $\mathrm{C} 1$ or $\mathrm{C} 5$ facies divisions. Facies B - mottled silty facies represent divisions $\mathrm{C} 2$ or $\mathrm{C} 4$. Facies $\mathrm{C}-$ mottled and 
bioturbated fine-grained sandy facies can be assigned to the $\mathrm{C} 3$ division and represent an increase in bottom current velocity and/or an increase in sandy sediment supply. However, the massive and laminated medium-grained sand (Facies D), and coarse sandy and gravel facies (Facies E) are not easily represented by the $\mathrm{C} 3$ division. The current study's findings suggest that a new sandy contourite facies model is required (see Discussion).

\section{Facies sequences}

Diverse combinations of Facies A to E are observed in the studied cores, which give a variety of different sedimentary sequences including: bi-gradational sequences; fining upward sequences; coarsening upward sequences; and massive sandy sequences. These can be matched to the standard contourite sequence definitions as defined by Stow et al. (2002) and Stow \& Faugères (2008); (i) complete bi-gradational contourite sequence $\mathrm{C} 1$ to $\mathrm{C} 5$; (ii) mid-only sequence $\mathrm{C} 2$ to $\mathrm{C} 4$; (iii) base-cut sequence $\mathrm{C} 3$ to $\mathrm{C} 5$; (iv) top-cut sequence $\mathrm{C} 1$ to $\mathrm{C} 3$; and (v) C3-only contourite sands (Fig. 9). In some cases, the sands of Facies D and $\mathrm{E}$ do not easily fit into the standard bi-gradational sequence.

\section{Bi-gradational sequences}

Bi-gradational sequences can consist of the full range of facies from mud to sand (reverse grading), and back to mud (normal grading). There are also a number of examples that lack in $\mathrm{C} 1$ and $\mathrm{C} 5$ muddy divisions. These reflect a dominantly silty-sandy contourite facies succession that is made up of divisions $\mathrm{C} 2$ to $\mathrm{C} 4$ only. These are most commonly found in cores collected from channel localities where bottom currents are amplified (Hernández-Molina et al., 2014). They are common in cores PC06 and U1388 collected from a contourite channel and adjacent plastered drift on the Upper Slope (Figs 2 and 9). Other bi-gradational sequences excluding the C3 sandy division are seen in PC04 (Fig. 9). These facies sequences are most prevalent on contourite drifts where the transport capacity and erosional capability of the Mediterranean Outflow Water is diminished.

\section{Base-cut sequence C3 to C5}

Base-cut contourite sequences are essentially normally graded, and made up of divisions C3 to C5. Examples are seen in core U1388, located in the northern contourite channel (Figs 2 and 9). There is a relatively abrupt or erosional boundary at the base of the sequence, separating the underlying finergrained sediment from the overlying sandy facies. This may be disrupted by large-scale bioturbation. 
The overlying sand-dominated or silt-dominated divisions are generally structureless and heavily bioturbated.

\section{Top-cut sequence C1 to C3}

Some clear examples of top-cut contourite facies sequences are seen in PC04 and PC08 collected from a mounded drift adjacent to a contourite channel (Figs 2 and 9). Top-cut sequences show reverse grading (divisions $\mathrm{C} 1$ to $\mathrm{C} 3$ ) and are topped by an abrupt or erosional boundary. Where overlain by finer-grained facies, bioturbation is commonly seen penetrating downward into the underlying unit. Distinct bioturbational characteristics are evident in each division; muds are heavily bioturbated and small-scale burrows occur throughout, whereas divisions C2 and C3 show a more mottled appearance with some larger ( $>1 \mathrm{~cm}$ diameter) burrows observed. In some cases, the overlying sequence shows a thin section of normal grading at its base overlain by a reverse grading trend. Such thin (1 to $2 \mathrm{~cm}$ scale) bottom-cut-out contourite sequences appear to be common above top-cut-out contourite sequences (see also PC08, 2.75 mbsf; Fig. 9).

\section{C3-only contourite sands}

The cores reveal a number of sand-rich sequences that show no grading, but instead are structureless and thick-bedded. Some of these are made up of the C3 division of the contourite sequence model, whereas others do not fit into the standard model. Core sites U1388 and PC06, collected from within contourite channels proximal to the Strait of Gibraltar, show the best examples. They consist of sanddominated beds bounded by erosional scour surfaces both to the top and bottom (Fig. 9). Such facies are commonly made up of medium to coarse-grained sands and show little evidence of bioturbation [except for rare large ( $>1 \mathrm{~cm}$ diameter) burrows]. The main 'structures' to note are localized coarse lags and lenses. In some rare examples, laminated beds are observed (for example, U1388 5.2 mbsf; BC05). Medium sands deposited in high-energy contourite channels (as seen in U1388) are generally structureless with erosional surfaces and local coarse lag lenses, whereas the coarser-grained sands may show lamination (BC05). This is in contrast to finer contourite sands deposited on contourite drifts (for example, PC04), which may rarely show indistinct lamination, but are mostly bioturbated. 


\section{Contourite sand texture}

This study presents one of the largest records of sedimentological data in any modern sandy contourite depositional system to date. The grain-size statistics and distribution curves reveal information on depositional processes and sediment supply.

\section{Mean grain-size}

The studied sediment samples show mean grain sizes from $6 \mu \mathrm{m}$ to $c a 1000 \mu \mathrm{m}$. Because they are contourite sediments, transported and deposited by bottom currents, a strong link between mean grain size and current velocity (or carrying capacity) should be expected. This is confirmed with the observed coarsest grained sediments accumulating in areas of amplified bottom current velocities (for example, BC05 and U1388 located within the contourite channels) and the finest grained sediments being collected from sites more distal from the MOW flow (for example, PC08). There is not, however, a direct linear correspondence for a number of reasons (McCave, 1984; Stow et al., 2008; Stow et al., 2012; Mulder et al., 2013):

- The finest portion of the sediment (clays and fine silts) is most likely to be transported as flocculated particles that are disaggregated during the grain-size analysis. The resulting grain-size distributions and statistics do not, therefore, accurately reflect the hydrodynamic grain size during transport (McCave, 1984).

- The Cadiz contourites are of mixed siliciclastic-bioclastic composition. The coarser sediment therefore includes biogenic tests (foraminifera) and broken-up shell fragments that are hydrodynamically lighter than comparable siliciclastic grains and require lower velocities for transportation.

- Volume of sediment influx into the bottom current system from downslope supply as well as the different distances of transport for individual particles within the bottom current also play an important part in presenting a non-linear relationship between grain size and current velocity. This is observed with coarsest grained sediments being observed proximal to the Strait of Gibraltar, and across the uppermost continental slope (BC05 and PC06 respectively).

For the Gulf of Cadiz, in general, there is a well-documented trend of decreasing grain size associated with weakening bottom current velocity away from the Strait of Gibraltar (Nelson et al., 1993, 1999; Llave et al., 2007). More detailed studies, including the data presented in this paper, show 
focused sand accumulation in the parts of the system where bottom water is accelerated (for example, channel core sites BC05 and U1388; Hanquiez et al., 2010; Stow et al., 2013b).

\section{Sorting}

Previous studies have shown that contourites tend to be poorly sorted on account of sediment mixing by bioturbation and due to their mixed siliciclastic-bioclastic composition (e.g. Stow et al., 2002; Wetzel et al., 2008; Mulder et al., 2013). However, the data here show some sections of moderate sorting that appear to be broadly linked to mean grain size. Considering the relationship between sorting and mean grain size (Fig. 11), a number of trends can be seen. A significant trend of increased sorting with mean grain size occurs from medium-grained silts through to fine-grained sands. Examining the cumulative frequency curves for these average grain sizes (Fig. 7) and, in particular, the changes of curve trend, suggests a decrease in deposition from the suspended load, and an increasing portion of sediment being deposited from the saltation load with increasing grain size. This shows that as the bottom current velocity and carrying capacity increase, then less of the fine-grained fraction is deposited, but rather remains in suspension and is transported in the water mass.

This distinctive trend is interpreted as a typical depositional trend for contourite deposits. At the finest end of the muddy contourite spectrum, this trend is reversed to give increased sorting with decreasing grain size, as displayed by the fine-grained silts and clays from PC04 and PC08, collected from a mounded drift (Fig. 11). A smooth cumulative frequency curve for fine-grained silts (Fig. 7) reflects deposition from very weak bottom currents capable of transporting only the finest silts and clays in suspension, as well as background hemipelagic deposition. The decreasing sorting trend as grain sizes increase to silts is interpreted to be due to increasing rates of bioturbation and mixing with other facies. Data points representing medium and coarse-grained sands (collected from BC05 and U1388 located within contourite channels) show better sorting than the muddy and silty contourites (Fig. 11) and a complete absence of a clay, silt or fine-grained sand fraction (Fig. 7). The cumulative frequency curves show the addition of a traction load component to the deposited sediment (Fig. 7). This reflects the action of strong winnowing (and erosional) processes at these core sites. The sediments never exceed moderate sorting, probably due to a mixed bioclastic-siliciclastic sediment composition, including large bioclastic fragments with smaller lithic grains (Fig. 10E). 
Two parallel but distinct trends are noted for samples from PC04 and PC06 (Fig. 11); this is inferred to be due to differences in sediment source. The bioclast and lithic grains collected from core sites BC05, PC04 and PC08 are associated with the Southern channel (Fig. 2). Tracing this channel back towards the Strait of Gibraltar it can be said that sediments were most likely derived from erosion within the Strait and its adjacent margins. PC06, however, is from a plastered drift along the upper slope (Fig. 2). Sediment supply to the PC06 core is therefore inferred to have some component fed from downslope supply (turbidity currents and spillover processes; Armishaw et al., 2002; Nelson et al., 1993, 1999; Hernandez-Molina et al., 2014) as well as alongslope bottom currents.

In summary, the sorting-grain-size trends observed are explained by a combination of current strength, sediment supply and the rate of bioturbation. Fine muddy contourites are influenced by weak bottom currents that supply and transport only fine-grained material. The sediment is completely reworked by bioturbation, and very little coarse material can reach the system. These finest grained sediments show poor sorting. The fine mottled silt-mud contourites (coarse silts and very fine-grained sands) show the worst sorting; poor to very poor. The slightly elevated current speed allows transport and deposition of clay, silt and very fine sand, but little or no winnowing once deposited. There is also extensive bioturbation, which enables the thorough mixing of all size components. Sand-rich contourites deposited by stronger currents (fine-grained and medium-grained sands) show a trend towards improved sorting. This is inferred to be mainly due to increased winnowing. Coarse-grained sands return to poorer sorting on account of a higher bioclastic component.

\section{Skewness and kurtosis}

There are very few studies that specifically describe contourite sand skewness (Lovell \& Stow, 1981; Stow et al., 1998, 2002) and these authors have suggested that skewness can be used to aid interpretation of sandy facies as contourites. Specifically, they argue that a coarse-tail skew is characteristic of sandy contourites subjected to winnowing. This is certainly seen in this very large dataset, in particular in the proximal channel sands of cores BC05 and U1388, in which the medium and coarse sands (apart from two data points) show a progressive trend towards coarse or very coarse skew (Fig. 5B). It is inferred that prolonged winnowing action has removed the silt and clay fraction into suspension such that only the tractional bedload remains. The kurtosis values show that they are mesokurtic and platykurtic, which is evidence of multiple sediment sources (bimodal or polymodal distributions) as well as moderate sorting (Folk \& Ward, 1957) (Fig. 5C). 
The finest muds, by contrast, show a more or less symmetrical or normal distribution with zero or low skewness values, which is characteristic of sediments deposited by settling processes, i.e. hemipelagic deposition or very fine-grained contourites $(<15 \mu \mathrm{m})$ influenced by weak $(<10 \mathrm{~cm} / \mathrm{s})$ bottom currents with a fine suspension load. These are also platykurtic to mesokurtic in character, indicating broad grain-size distribution and multiple sediment sources. Increasing grain sizes to coarse silts and fine-grained sands show a progressively more fine skewed distribution up to a grain size of 50 to $60 \mu \mathrm{m}$, and then a decrease. This trend is interpreted as characteristic of a contourite depositional environment in which the carrying capacity of the current is the limiting factor in transport and where floccing is prevalent. The marked change in trend, which occurs at 50 to $60 \mu \mathrm{m}$, coincides with an increase in bedload transport by saltation and the onset of winnowing as an important process. The depositional trend is also characterized by a progressive change from platykurtic to very leptokurtic distributions. The latter are indicative of a single dominant sediment supply expressed as a unimodal distribution and/or good sorting (Folk \& Ward, 1957).

These same trends and data clusters are recognized on the cross-plot of skewness and sorting (Fig. 12). In this plot, the mean grain size is colour-coded so that its control can be imaged clearly, and summary distributions are outlined for each distinct grain size (Fig. 12). The other cross-plots in this study also show that there is a strong link between grain size and different statistical parameters. This shows that velocity (and thus transport capacity of the current) exerts a strong control on grain-size distribution. However, the varied and complex patterns observed in cross-plots indicate that there is an additional range of controls on contourite sedimentation including: (i) different transport and depositional mechanisms, such as bedload, suspended load and settling; (ii) mixed sediment sources bottom current, turbidity current and hemipelagic supply; and (iii) post-depositional bioturbation.

\section{DISCUSSION}

This section discusses: (i) the key features of the contourite sediments recovered along the slope of the eastern Gulf of Cadiz; (ii) their textural characteristics and key insights on contourite depositional processes; and (iii) a new facies model for contourite sands, at core and sediment scale, and how this differs from other deep-water facies models. 


\section{Characterizing contourite facies}

General facies characteristics for the identified sand-rich contourite depositional system along the slope of the eastern Gulf of Cadiz are: (i) indistinct bedding with sharp or gradational contacts; (ii) a typical absence or lack of preservation of primary sedimentary structures and presence of bioturbation; (iii) fine mud to medium-grained sand textures with very poor to poor sorting dominating and only rare moderate sorting; (iv) mixed terrigenous-biogenic composition, and mixed shallow to deep-water components; and (v) bi-gradational sequences, with common partial sequences of coarsening-up and fining-up grain size. There is a distinctive uniformity of appearance between all sites in the study area and with contourite facies from other parts of the Cadiz region. Key diagnostic criteria are outlined below.

\section{Discontinuities}

Sharp boundaries are common in the contourite sands observed; they are all interpreted as representing an increase in energy, or bottom current velocity, to a point of non-deposition and/or erosion. In some cases, they have been partially homogenized due to bioturbation. Erosional discontinuities are more commonly associated with coarser sediment, and especially with massive sands and laminated sands observed in cores collected from the contourite channels. This is commensurate with higher bottom current velocity in these regions, but can also indicate downslope sediment supply and local erosion via turbidity currents.

\section{Primary sedimentary structures}

The fine-grained contourites (especially muds and silts) examined in this study show little to no primary sedimentary structures such as lamination and cross-lamination. According to most previous studies this is the norm for contourite drift sediments (e.g. Stow \& Faugères, 2008), and is due to a lack of preservation of original structures as a result of extensive reworking by bioturbation (Wetzel et al., 2008). This is true also for fine-grained sands, whereas the medium and coarse sands show a significant decrease in the extent of bioturbation, and therefore should be more likely to preserve primary sedimentary structures. Some beds, generally restricted to channel localities such as BC05 show lamination. However, for most of the sandy contourites in this study there is a distinct lack of any structures, or only subtle hints of structure (Fig. 10D). One possible cause of this is the highly fluidized nature of the soft sediment contourite sand cores that results in the destruction of structures during the core acquisition process. For example, the uppermost section of PC06 has been greatly fluidized on acquisition and transportation due to the unconsolidated and coarse-grained nature of the 
sediment. Therefore, the original sedimentary features have not been preserved in the top $40 \mathrm{~cm}$ (Fig. 3). Nevertheless, there are thick sections of sandy core at depth that are structureless and yet appear to have been undeformed by the coring process. The mechanism for forming these massive sands remains an outstanding question.

\section{Bioturbation}

Bioturbation is commonly used as a key diagnostic tool for the identification of contourite sediments, in particular for the muddy to sandy contourites of the standard sequence model (Gonthier et al., 1984; Stow \& Faugères, 2008). However, the study of contourite ichnology is still very much in its infancy (Baldwin \& McCave, 1999; Löwemark et al., 2004; Shanmugam, 2006; Wetzel et al., 2008; Essex \& Stow, 2013) and a definitive ichnofacies model for contourite deposition is yet to be developed (Bromley, 1996). The bioturbation style and trace fossil types observed in this study are broadly comparable to those observed in contourites elsewhere, as outlined by (Wetzel et al., 2008), including a clear link between grain size and ichnofacies. The key observations regarding trace fossil style for the $\mathrm{C} 1$ to $\mathrm{C} 5$ facies divisions are listed below.

Muddy contourite facies ( $\mathrm{C} 1$ and $\mathrm{C} 5$ divisions) are heavily bioturbated, but with a moderate diversity of ichnofossils. There is intense bio-deformation by small-scale (millimetre-diameter) burrowers such as Chondrites leading to a very subtle mottled appearance. Several generations of burrows may be evident, including larger-diameter (centimetre-scale) traces. This complete sediment reworking is attributed to sluggish $(<10 \mathrm{~cm} / \mathrm{sec})$ bottom currents providing ventilation and nutrients to the sea floor that promotes benthic communities.

Mottled silt and very fine-grained sandy contourite facies (C2 and C4 divisions) are also heavily bioturbated, but with a greater diversity of burrowers than the muddy contourites. There is a very distinctive mottled appearance from intense bio-deformation and multiple generations of ichnofossils. Burrow size ranges from millimetre to centimetre. It is inferred that more energetic $(10$ to $15 \mathrm{~cm} / \mathrm{sec})$ bottom currents provide enhanced ventilation and nutrients to the sea floor that promotes still more active benthic communities, larger organisms and a greater biodiversity compared with muddy contourites (Wetzel et al., 2008). 
The fine-grained sandy contourite facies (C3 division) recovered from some of the more proximal drift cores in this study show less bioturbation, with fewer, large burrows such as Thalassinoides and Planolites. Locally, hints of laminations are present, indicating less-extensive sediment reworking by bioturbation. This change of ichnofacies is thought to be due to the increasing bottom current velocities required for fine sand deposition coupled with the removal of the silt and clay fraction. More vigorous currents restrict habitation of the sea floor, as small organisms and juveniles are swept away. Therefore, it is only larger species, and deep penetrating burrowers that are able to survive (Wetzel et al., 2008).

Medium to coarse-grained sandy facies only rarely show any trace fossils indicating that bottom current velocity or accumulation rates were sufficiently high to prevent the habitation of the sea bed by fauna. Where the core reaches high sand content (greater than $70 \%$ ) there is a marked reduction in bioturbation of the sediment. For clean medium-grained to coarse-grained sands to be deposited, vigorous bottom currents on the order of 50 to $100 \mathrm{~cm} / \mathrm{sec}$ are expected (Stow et al., 2009) and this is generally too hostile an environment for bottom feeders. Deep burrowing organisms may survive, but the removal of juvenile organisms makes it difficult for a community to establish. The boundaries between this and other facies are often abrupt and erosional. In some cases, amalgamated sands are seen (as in the channel deposits at core site U1388), which can significantly increase the thickness of sandy facies.

\section{Towards a new sand-rich contourites facies model}

Compiling the observations and interpretations of the cores in this study, collected from a sand-rich contourite depositional system, a revised set of facies models is proposed to aid in distinguishing contourite deposits from other deep-water sandy facies.

\section{The standard contourite facies model}

Fine-grained contourite sands commonly form the $\mathrm{C} 3$ division of the standard contourite facies model (Fig. 13). Muddy contourites are fine and very fine-grained (mainly $\mathrm{C} 1$ and $\mathrm{C} 5$ divisions). They show few to no erosional boundaries, but rather gradational changes between facies and continuous sedimentation. They are extensively bioturbated with a wide range of trace fossils often cross-cutting one another. Sediment sorting is poor to very poor, there is a near symmetrical grain-size distribution (zero to very low skewness values) (Fig. 14), and a platykurtic or mesokurtic character. These features 
are quite distinctive from those of fine-grained turbidites, which typically show sedimentary structures throughout, partial standard sequences, distinct erosional basal boundaries, and normal grading or graded laminated units as the result of event deposits. However, there are close similarities with hemipelagic sediments, from which they are hard to distinguish (Stow \& Tabrez, 1998; Stow \& Faugères, 2008).

The $\mathrm{C} 2-\mathrm{C} 3-\mathrm{C} 4$ divisions comprise mottled silts and fine-grained muddy sands (Fig. 13). Omission surfaces, hiatuses and minor erosive boundaries occur in any of these divisions, although the erosive contacts are more common in $\mathrm{C} 3$, and deposition is semi-continuous. Bi-gradational sequences are common, with mostly gradational boundaries and a sequence of ichnofacies associated with the different divisions. A range of partial sequences are observed in the study, as has also been reported in the distal part of the Gulf of Cadiz contourite depositional system (Alonso et al., 2016). Small-scale cyclicity is represented by subtle changes in grain size (Jones, 2016). The fine muddy sands of the C3 division rarely exceed $1 \mathrm{~m}$ in thickness. These silty to very fine sandy contourites are moderate to very poorly sorted, have a fine to very fine skew, and range from mesokurtic to very leptokurtic (Fig. 14). These features differ markedly from those of turbidites, which are characterized by partial or complete Bouma Sequences, with erosional bases, normal grading and common primary sedimentary structures. If bioturbation is present in turbidites, it occurs as a top-down feature extending downwards from the muddy E-division. The amount of bioturbation and depth of penetration within the Bouma Sequence depends largely on the time between turbidity current events (Wetzel et al., 2008).

\section{Fine to medium-grained sandy contourite facies}

Fine to medium-grained contourite sands, in general, were not seen to occur as part of a standard contourite sequence (or associated top-cut, base-cut variations), rather they tend to occur as distinct units. Two dominant fine to medium-grained sandy contourite facies types can be identified: (i) finegrained bioturbated sandy facies; and (ii) fine-grained or medium-grained, clean (mud-free) sands that are mostly structureless sands with rare bioturbation. Rare laminated medium sands also occur. Bioturbated fine sands are typical of contourite mounded, or plastered drifts (as seen in cores PC04 and PC06), whereas massive and rare laminated facies occur in higher-energy sandy sheeted drifts and contourite channels (U1388). There is a marked reduction of bioturbation compared with mediumgrained contourites, although where present it is larger scale. Erosional and non-depositional surfaces are common. They differ from coarse-grained turbidite facies by their lack of any normal grading, the rare presence of large scale trace fossils (Fig. 13), and their relative lack of any water escape 
structures (except where core acquisition has caused deformation as is seen in unit 1 of PC06). This study has shown that sandy contourites range from poorly sorted to moderately sorted and have a coarse skew on account of winnowing and non-deposition of the finer sediment portion (Fig. 14).

\section{Coarse-grained sandy and gravel lag contourite facies}

Finally, coarse-grained sand and gravel lag facies were poorly represented in this dataset (only observed in contourite channel site $\mathrm{BC} 05$ ). This is also the case in contourite deposits worldwide, with coarse contourite accumulations being extremely rare. They have been seen in other studies in the Gulf of Cadiz (Stow et al., 2013b), and have been collected by BC05 in this study. These facies typically comprise thin gravel-rich layers within a medium-grained to coarse-grained sand and can show lamination. Unlike coarse-grained turbidites or downslope mass wasting deposits (debrites), these gravel facies tend to be laterally constricted and relatively finer grained. This is not surprising on account of the large amount of energy required to transport such grain sizes in bottom currents. As a result, they tend to be limited to contourite channels (for example, BC05). They rely on a local sediment supply of gravel and coarse sand and abnormally vigorous bottom currents $(>50 \mathrm{~cm} / \mathrm{sec})$ and occur principally within contourite channel systems (Stow et al., 2013b; Hernández-Molina et al., 2014).

\section{CONCLUSIONS}

The results presented document the world's largest present-day sand-rich deep-water contourite depositional system, which extends over an area of $4000 \mathrm{~km}^{2}$ west and north-west from the exit of the Strait of Gibraltar. This has accumulated at mid-slope depths (500 to $1200 \mathrm{~m}$ ) under the influence of the Mediterranean Outflow Water (MOW). All sediments examined for this study can be reliably interpreted as contourites on the basis of their oceanographic setting, seismic and morpho-sedimentary features, and detailed facies characteristics. However, there is a wide range of contourite facies present - not only sands. These include: (i) bioturbated muddy contourites; (ii) mottled silty contourites; (iii) very fine-grained mottled and fine-grained bioturbated sandy contourites; (iv) massive and laminated medium-grained sandy contourites; and (v) coarse-grained sandy/gravel contourites. These facies tend to co-occur in partial and full bi-gradational facies sequences. 
Grain-size analysis of 675 samples from the eastern Gulf of Cadiz reveals distinctive trends in textural properties linked to depositional process under the action of bottom currents (Fig. 14). The finest muddy contourites $(<20 \mu \mathrm{m})$ show normal grain-size distributions, poor to very poor sorting, zero or low skewness, and platykurtic to mesokurtic kurtosis. These are deposited by settling from weak $(<10 \mathrm{~cm} / \mathrm{sec})$ bottom currents with a fine suspension load. Muddy to fine sandy contourites (20 to $200 \mu \mathrm{m}$ ) show a uniform trend towards better sorting and a more leptokurtic distribution. They show a progressively finer skewed distribution up to a grain size of 50 to $60 \mu \mathrm{m}$, and then a decrease. These are the typical depositional trends for contourites - as velocity and carrying capacity increase (from 10 to $50 \mathrm{~cm} / \mathrm{sec}$ ), then more of the finest fraction remains in suspension. From 50 to $60 \mu \mathrm{m}$, bedload transport (principally saltation load) becomes more important than suspension transport and there is a marked increase in winnowing. Clean sandy contourites $(>200 \mu \mathrm{m})$ from the study area show a range of textural properties. They are better sorted than the fine muddy contourites and have no clay content, but display varied skewness and kurtosis values. These contourites result from the action of dominant bedload transport (saltation and traction), strong winnowing and local erosion at current speeds in excess of around 50 to $70 \mathrm{~cm} / \mathrm{sec}$.

Important controls on the nature and distribution of contourites; their textural, ichnofacies and facies models, include: (i) transport and depositional processes from bottom currents and their velocity variation; (ii) sediment supply from mixed sources; and (iii) the post-depositional action of burrowing organisms.

The results presented from the Gulf of Cadiz contourite depositional system provide an important modern analogue for contourite sands in the subsurface. Research into contourite sands and other sandy deposits generated or affected by bottom currents is in its infancy. A better understanding of their sedimentary facies associations is required because these deposits are expected to become important for hydrocarbon exploration in next decades. The study of contourites and related sands is a novel and rapidly expanding area of research and a collective effort towards their accurate interpretation and understanding is required. Therefore, further studies along other margins should clarify the real distinction between sandy contourites and reworked deep-water sands derived from turbiditic and other processes. Such studies will test the facies model proposed in the Gulf of Cadiz against other margins with various geological and oceanographic configurations. 


\section{ACKNOWLEDGEMENTS}

This research used samples and data collected through the Integrated Ocean Drilling Program (IODP) Expedition 339 on board JOIDES Resolution, and recent Spanish research expeditions on board the Sarmiento de Gamboa. In each case we thank the captain, crew and shipboard scientists. This research formed part of the lead author's PhD programme at Heriot-Watt University, supported by an Ali Danesh Scholarship and of the Masters by research from Claudia Jones in the Department of Earth Sciences of the Royal Holloway University of London. The research was also partially supported through the Spanish Ciencia y Tecnologías Marinas projects CTM 2012-39599-C03, CGL2016-80445-R, and CTM2016-75129-C3-1-R, and conducted in the framework of "The Drifters" Research Group of the Royal Holloway University of London (RHUL). Radiocarbon Dating Lab in the Laboratoire de Mesure du Carbone 14 (France) is thanks to the French Artemis Program.

\section{REFERENCES}

Akhmetzhanov, A., Kenyon, N., Habgood, E., Ven Der Mollen, A., Nielsen, T., Ivanov, M. and Shashkin, P. (2007) North Atlantic contourite sand channels. In: Economic and Palaeoceanographic Significance of Contourite Deposits (Eds A. Viana and M. Rebesco), Geological Society, London, Special Publication 276, 25-47.

Alejo, I., Nombela, M., Ercilla, G., Brackenridge, R., Francés, G., Pérez-Arlucea, M., Mena, A., Hernández-Molina, F., Stow, D.A.V. and Medialdea, T. (2012) Caracterización de los sedimentos superficiales en tres sistemas deposicionales contorníticos (Golfo de Cádiz, Cabo Ortegal y El Cachucho): implicaciones conceptuales. (Recent sediments characterization of three contourite depositional systems (Gulf of Cadiz, Ortegal Spur and El Cachucho): conceptual implications). Geo-Temas, 13, 535-236.

Alonso, B., Ercilla, G., Casa, D., Stow, D.A.V., Rodrígueaz-Tovar, F.J., Dorador, J. and Hernández -Molina, F.J. (2016) Contourite vs. gravity-flow deposits of the Pleistocene Faro Drift (Gulf of Cadiz): Sedimentological and mineralological approaches. Marine Geology, 377, 77-94.

Ambar, I., Armi, L., Bower, A. and Ferreira, T. (1999) Some aspects of time variability of the Mediterranean Water off south Portugal. Deep-Sea Research Part I-Oceanographic Research Papers, 46, 1109-1136.

Ambar, I., Serra, N., Brogueira, M., Cabecadas, G., Abrantes, F., Freitas, P., Goncalves, C. and Gonzalez, N. (2002) Physical, chemical and sedimentological aspects of the Mediterranean

This article is protected by copyright. All rights reserved. 
outflow off Iberia. Deep-Sea Research Part II-Topical Studies in Oceanography, 49, 41634177.

Ambar, I. and Howe, M. (1979) Observations of the Mediterranean Outflow 1. Mixing in the Mediterranean Outflow. Deep-Sea Research Part I-Oceanographic Research Papers, 26, 535-554.

Antich, N., Buitrago, J., García Mojonero, C., Jiménez, A. and Martínez del Olmo, W. (2005) Contourites: An unknown and excellent reservoir (Gulf of Cadiz, SW Spain). In: Libro 25 Aniversario (Ed. W. Martinez del Olmo), pp. 75-82. Associatión de Geólogos y Geofisicos Españoles del Petróleo (AGGEP), Madrid.

Baldwin, C. and McCave, I. (1999) Bioturbation in an active deep-sea area: implications for models of trace fossil tiering. Palaios, 14, 375-388.

Baringer, M. and Price, J. (1997). Mixing and spreading of the Mediterranean outflow. Journal of Physical Oceanography, 27, 1654-1677.

Baringer, M. and Price, J. (1999) A review of the physical oceanography of the Mediterranean outflow. Marine Geology, 155, 63-82.

Blott, S. and Pye, K. (2001) GRADISTAT: A grain size distribution and statistics package for the analysis of unconsolidated sediments. Earth Surface Processes and Landforms, 26, 1237 1248 .

Brackenridge, R., Hernández-Molina, F., Stow, D. and Llave, E. (2013a) A Pliocene mixed contourite-turbidite system offshore the Algarve Margin, Gulf of Cadiz: seismic response and implications for the evolution of the margin. Marine and Petroleum Geology, 46, 36-50.

Brackenridge, R., Hernández-Molina, F., Stow, D.A.V., Mena, A., Alejo, I., Ercilla, G., Francés, G., Llave, E., Nombela, M., Perez-Arlucea, M. and CONTOURIBER Team. (2013b) A contourite sand sheet east of the Strait of Gibraltar; a sedimentological study revealing the complexity of high energy bottom water systems in the Gulf of Cadiz. International Association of Sedimentologists, Annual Meeting 2014. Manchester, UK. 
Bromley, R. (1996) Trace Fossils: Biology, Taxonomy and Applications. Chapman and Hall, London, $378 \mathrm{pp}$.

Buitrago, J., Garcia, C. and Cakebread-Brown, J. (2001) Contouritas: Un excelente almacén casi desconocido (Golfo de Cádiz, SO de España). ler Congreso Técnico Exploración y Producción REPSOL-YPF. Septiembre 2001. Madrid, Spain. Abstract Volume 24-27.

Cabecadas, G., Brogueira, M. and Goncalves, C. (2002) The chemistry of Mediterranean outflow and its interactions with surrounding waters. Deep-Sea Research Part II-Topical Studies in Oceanography, 49, 4263-4270.

Cooper, J. (1998) Particle Size Analysis - The Laser Diffraction Technique. Materials World, 6, 5-7.

Ercilla, G., Casas, D., Hernández-Molina, F.J., Roque, C. and MOWER cruise team (2015) Bottom current-generated bedforms: the action of the MOW (Mediterranean outflow) at the exit of the Strait of Gibraltar. In: Atlas of Bedforms in the Western Mediterranean (Eds J. Acosta, S. Berné, F. Chiocci, A. Palanques and J. Guillen), Elsevier, Netherlands

Esentia, I., Stow, D., and Smillie, Z. (2017) Contourite drifts and associated bedforms. In: Submarine Geomorphology (Eds A. Micallef, S. Krastel and A. Savini), pp. 301-33. Springer Geology.

Essex, H. and Stow, D.A.V. (2013) The ichnology of contourites. International Association of Sedimentologists Annual Meeting. Manchester, UK, Abstract Volume T3S4_P25.

Esteras, M., Izquierdo, J., Sandoval, N. and Bahmad, A. (2000) Evolución morfológica y estratigráfica Plio-Cuaternaria del Umbral de Camarinal (Estrecho de Gibraltar) basada en sondeos marinos. Revista de la Sociedad Geológica de España, 13, 539-550.

Expedition 339 Scientists (2012) Site U1388 Summary. IODP Expedition 339: Mediterranean Outflow. Site Summaries. International Ocean Discovery Program. Available at: http://iodp.tamu.edu/scienceops/sitesumm/339/339_ss1388.html.

Faugères, J., Gonthier, E. and Stow, D. (1984) Contourite drift molded by deep Mediterranean Outflow. Geology, 12, 296-300.

This article is protected by copyright. All rights reserved. 
Faugères, J., Lima, A., Masse, L. and Zaragosi, S. (2002) The Columbia channel-levee system: A fan drift in the southern Brazil Basin. In: Deep-Water Contourtite Systems: Modern Drifts and Ancient Series, Seismic and Sedimentary Characteristics (Eds D. Stow, C. Pudsey, J. Howe, J. Faugères and A. Viana), Geological Society Special Publicaitons, London, 223-238.

Faugères, J., Stow, D.A.V., Imbert, P. and Viana, A. (1999) Seismic features diagnostic of contourite drifts. Marine Geology, 162, 1-38.

Folk, R. (1964) A review of grain-size parameters. Sedimentology, 6, 73-93.

Folk, R. and Ward, W. (1957) Brazos River Bar: a study in the significance of grain size parameters. Journal of Sedimentary Petrology, 27, 3-26.

Garcia-Lafuente, J., Delgado, J., Criado-Aldeanueva, F., Bruno, M., del Rio, J. and Vargas, J. (2006) Water mass circulation on the continental shelf of the Gulf of Cadiz. Deep-Sea Research Part II-Topical Studies in Oceanography, 53, 1182-1197.

Gonthier, E., Faugères, J.-C. and Stow, D. (1984) Contourite facies of the Faro Drift, Gulf of Cadiz. In: Fine-Grained Sediments: Deep-Water Processes and Facies (Eds D. Stow and D. Piper) Geological Society Special Publication, London, 275-292.

Habgood, E., Kenyon, N., Masson, D., Akhmetzhanov, A., Weaver, P., Gardner, J. and Mulder, T. (2003) Deep-water sediment wave fields, bottom current sand channels and gravity flow channel-lobe systems: Gulf of Cadiz, NE Atlantic. Sedimentology, 50, 483-510.

Hanquiez, V., Mulder, T., Lecroart, P., Gonthier, E., Marches, E. and Voisset, M. (2007). High resolution seafloor images in the Gulf of Cadiz, Iberian margin. Marine Geology, 246, 42-59.

Hernández-Molina, F.J., Llave, E., Somoza, L., Fernandez-Puga, M., Maestro, A., Leon, R., Medialdea, T., Barnolas, A., Garcia, M., del Rio, V., Fernandez-Salas, L., Vazquez, J., Lobo, F., Dias, J., Rodero, J. and Gardner, J. (2003) Looking for clues to paleoceanographic imprints: A diagnosis of the Gulf of Cadiz contourite depositional systems. Geology, 31, 19-22. 
Hernández-Molina, F.J., Llave, E., Stow, D.A.V., Garcia, M., Somoza, L., Vazquez, J., Lobo, F., Maestro, A., del Rio, V., Leon, R., Medialdea, T. and Gardner, J. (2006) The contourite depositional system of the Gulf of Cadiz: A sedimentary model related to the bottom current activity of the Mediterranean outflow water and its interaction with the continental margin. Deep-Sea Research Part II-Topical Studies in Oceanography, 53, 1420-1463.

Hernández-Molina, F.J., Llave, E., Preu, B., Ercilla, G., Fontan, A., Bruno, M., Serra, N., Gomiz, J., Brackenridge, R., Sierro, F., Stow, D.A.V., Garcia, M., Juan, C., Sandoval, N. and Arnaiz, A. (2014) Contourite processes associated with the Mediterranean Outflow Water after its exit from the Gibraltar Strait; global and conceptual implications. Geology, $\mathbf{4 2}$, 231-234.

Hernández-Molina, F.J., Sierro, F.J., Llave, E., Roque, C., Stow, D.A.V., Williams, T., Lofi, J., Van der Schee, M., Arnaiz, A., Ledesma, S., Rosales, C., Rodriguez-Tovar, F.J., PardoIguzquiza, E. and Brackenridge, R.E. (2016) Evolution of the Gulf of Cadiz margin and southwest Portugal contourite depositional system: Tectonic, sedimentary and paleoceanographic implications from IODP expedition 339. Marine Geology, 337, 7-39.

Howe, M. (1982). The Mediterranean Water Outflow in the Gulf of Cadiz. Oceanography and Marine Biology, 20, 37-64.

Ito, M. (1996) Sandy contourites of the Lower Kazusa Group in the Boso Peninsula, Japan: Kuroshio current influenced deep-sea sedimentation in a Plio-Pleistocene forearc basin. Journal of Sedimentary Research, 66, 587-598.

Jones, C. (2016) Sandy contourite deposits in the Gulf of Cadiz: Sedimentological aspects and its evolutionary implication with the Gibraltar Gateway. MSc Earth Science by Research, RHUL, UK, 158 pp.

Kelling, G., and Stanley, D. (1972) Sedimentary evidence of bottom current activity, Strait of Gibraltar region. Marine Geology, 13, 51-60.

Kenyon, N. and Belderson, R. (1973) Bed forms of the Mediterranean undercurrent observed with side-scan sonar. Sedimentary Geology, 9, 77-99. 
Legg, S., Briegleb, B., Chang, Y., Chassignet, E., Danabasoglu, G., Ezer, T., Gordon, A., Griffies, S., Hallberg, R., Jackson, L. and Large, W. (2009) Improving oceanic overflow representation in climate models. The gravity current entrainment climate process team. Bulletin of the American Meteorological Society, 90, 657-670.

Lewis, D. and McConchie, D. (1994) Analytical Sedimentology. Springer, Boston, 197 pp.

Llave, E., Schonfeld, J., Hernández-Molina, F.J., Mulder, T., Somoza, L., Díaz del Rio, V. and Sanchez-Almazo, I. (2006) High-resolution stratigraphy of the Mediterranean outflow contourite system in the Gulf of Cadiz during the late Pleistocene: The impact of Heinrich events. Marine Geology, 227, 241-262.

Llave, E., Hernández-Moliana, F.J., Stow, D., Fernández-Puga, M., García, M., Vázquez, J., Maestro, A., Somoza, L. and Díaz del Río, V. (2007) Reconstructions of the Mediterranean Outflow Water during the Quaternary based on the study of changes in buried mounded drift stacking pattern in the Gulf of Cadiz. Marine Geophysical Research, 28, 379-394.

Lobo, F., Hernández-Molina, F.J., Somoza, L., Rodero, J., Maldonado, A. and Barnolas, A. (2000) Patterns of bottom current flow deduced from dune asymmetries over the Gulf of Cadiz shelf (southwest Spain). Marine Geology, 164, 91-117.

Lobo, F., Maldonado, A. and Noormets, R. (2010) Large-scale sediment bodies and superimposed bedforms on the continental shelf close to the Strait of Gibraltar: interplay of complex oceanographic conditions and physiographic constraints. Earth Surface Processes and Landforms, 35, 663-679.

Lovell, J. and Stow, D. (1981). Identification of ancient sandy contourites. Geology, 9, 347-349.

Löwemark, L., Schönfeld, J., Werner, F. and Schäfer, P. (2004) Trace fossils as a paleoceanographic tool: Evidence from Late Quaternary sediments of the southwestern Iberian margin. Marine Geology, 204, 27-41.

Maldonado, A., Rodero, J., Pallarés, L., Somoza, L., Medialdea, T., Hernández-Molina, F.J. and Lobo, F.J., (2003) Mapa Geológico 1:200.000 de la Plataforma Continental Española y Zonas Adyacentes. Memoria y Hoja no. 86-86S (Cádiz). Instituto Tecnológico GeoMinero de España (IGME), 91 pp. 
Maldonado, A., Somoza, L. and Pallares, L. (1999) The Betic orogen and the Iberian-African boundary in the Gulf of Cadiz: geological evolution (central North Atlantic). Marine Geology, 155, 9-43.

Martins, L. (2003) Recent sediments and grain-size analysis. Gravel, 1, 90-105.

McCave, I. (1984) Erosion, transport and deposition of fine-grained marine sediments. In FineGrained Sediments: Deep-Water Processes and Facies (Eds D. Stow and D. Piper) Geological Society, London, 35-69.

McCave, I., Bryant, R., Cook, H. and Coughanowr, C. (1986) Evaluation of a laser-diffraction-size analyzer for use with natural sediments. Journal of Sedimentary Petrology, 56, 561-564.

Medialdea, T., Somoza, L., Pinheiro, L., Fernandez-Puga, M., Vazquez, J., Leon, R., Ivanov, M., Magalhaes, V., Diaz-del-Rio, V. and Vegas, R. (2009) Tectonics and mud volcano development in the Gulf of Cadiz. Marine Geology, 261, 48-63.

Mena, A., Francés, G., Pérez-Arlucea, M., Aguiar, P., Barreiro-Vázquez, J.D., Iglesias, A. and Barreiro-Lois, A. 2015. A novel sedimentological method based on CT-scanning: Use for tomographic characterization of the Galicia Interior Basin. Sedimentery Geology, 321, 123 138.

Millot, C. (2009) Another description of the Mediterranean Sea outflow. Progress in Oceanography, 82, 101-124.

Mulder, T., Faugères, J.-C. and Gonthier, E. (2008) Mixed turbidite-contourite systems. In: Contourites (Eds M. Rebesco and A. Camerlenghi) Developments in Sedimentology, 60, 435-456.

Mulder, T., Hassan, R., Ducassou, E., Zaragosi, S., Gonthier, E., Hanquiez, V., Marches, E., Toucanne, S. (2013) Contourites in the Gulf of Cadiz: a cautionary note on potentially ambiguous indicators of bottom current velocity. Geo-Marine Letters, 33, 357-367. 
Mulder, T., Voisset, M., Lecroart, P., Le Drezen, E., Gonthier, E., Hanquiez, V., Faugères, J., Habgood, E., Hernández-Molina, F., Estrada, F., Llave-Barranco, E., Poirier, D., Gorini, C., Fuchey, Y., Voelker, A., Freitas, P., Sanchez, F., Fernandez, L., Kenyon, N. and Morel, J. (2003) The Gulf of Cadiz: an unstable giant contouritic levee. Geo-Marine Letters, 23, 7-18.

Nelson, C.H., Baraza, J. and Maldonaldo, A. (1993) Mediterranean Undercurrent Sandy Contourites, Gulf of Cadiz, Spain. Sedimentary Geology, 82, 103-131.

Nelson, C. H., Baraza, J., Maldonado, A., Rodero, J., Escutia, C. and Barber Jr, J. H. (1999) Influence of the Atlantic inflow and Mediterranean outflow currents on Late Quaternary sedimentary facies of the Gulf of Cadiz continental margin. Marine Geology, 155, 99-129.

Rebesco, M. and Camerlenghi, A. (2008). Contourites. Developments in Sedimentology, 60, Elsevier, Amsterdam, $688 \mathrm{pp}$.

Rebesco, M., Hernádez-Molina, F.J., Van Rooij, D. and Wåhlin, A. (2014) Contourites and associated sediments controlled by deep-water circulation processes: State-of-the-art and future considerations. Marine Geology, 352, 111-154.

Rorden, C. and Brett, M. (2005) MRIcro. Availabile online at: http://www. sph. sc. $\mathrm{edu} / \mathrm{comd} /$ rorden/mricro. html.

Rosenbaum, G., Lister, G. and Duboz, C. (2002) Reconstruction of the tectonic evolution of the western Mediterranean since the Oligocene. In: Reconstruction of the Evolution of the AlpineHimalayan Orogen (Eds G. Rosenbaum and G. Lister) Journal of the Virtual Explorer, Paper 6.

Shanmugam, G. (2006) Deep-water bottom currents. Handbook of Petroleum Exploration and Production, 5, 85-139.

Shanmugam, G. (2012) New Perspectives on Deep-Water Sandstones: Origin, Recognition, Initiation, and Reservoir Quality. Elsevier, Oxford, 544 pp. 
Shanmugam, G. (2013) New perspectives on deep-water sandstones: implications. Petroleum Exploration and Development, 40, 316-324

Shanmugam, G., Spalding, T. and Rofheart, D. (1995) Deep-marine bottom-current reworked sand (Pliocene and Pleistocene), Ewing Bank 826 Field, Gulf of Mexico. SEPM Core Workshop No.20, Turbidites and Associated Deep-Water Facies. Houston, 25-54.

Somoza, L., Diaz-del-Rio, V., Leon, R., Ivanov, M., Fernandez-Puga, M., Gardner, J., Hernández-Molina, F.J., Pinheiro, L., Rodero, J., Lobato, A., Maestro, A., Vazquez, J., Medialdea, T. and Fernandez-Salas, L. (2003) Seabed morphology and hydrocarbon seepage in the Gulf of Cadiz mud volcano area: Acoustic imagery, multibeam and ultra-high resolution seismic data. Marine Geology, 195, 153-176.

Stanley, D. (1993) Model for turbidite-to-contourite continuum and multiple process transport in deep marine settings: examples in the rock record. Sedimentary Geology, 82, 241-255.

Stow, D.A.V. (1977) Late Quaternary Stratigraphy and Sedimentation on the Nova Scotian Outer Continental Margin. Unpublished Ph.D. Thesis, Dalhousie University, Halifax, NS, 360 pp.

Stow, D.A.V. (1982) Bottom-currents and contourites in the North Atlantic. Bulletin de l' Institut Géologique du Bassin Aquitaine, 31, 151-166.

Stow, D.A.V. and Faugères, J.-C. (2008) Contourite facies and faces model. In: Contourites. (Eds M. Rebesco and A. Camerlenghi), Developments in Sedimentology, 60, 223-250.

Stow, D.A.V. and Lovell, J.P.B. (1979) Contourites: Their recognition in modern and ancient sediments. Earth Science Reviews, 14, 251-291.

Stow, D.A.V. and Piper, D.J.W. (1984) Deep-water fine-grained sediments: Facies model. In: FineGrained Sediments: Deep-Water Processes and Facies (Eds34 D. Stow and D. Piper) Geological Society Special Publications London, 15, 611-646.

Stow, D.A.V., and Tabrez, A.R. (1998) Hemipelagites: processes, facies and model. In: Geological Processes on Continental Margins: Sedimentation, Mass Wasting and Stability (Eds. M.S. 
Stoker, D. Evans and A. Cramp) Geological Society Special Publications London, 129, 317 337.

Stow, D.A.V., Faugères, J.-C. and Gonthier, E. (1986) Facies distribution and textural variation in Faro Drift contourites: Velocity fluctuation and drift growth. Marine Geology, 72, 71-100.

Stow, D.A.V., Faugères, J.-C., Viana, A. and Gonthier, E. (1998) Fossil contourites: a critical review. Sedimentary Geology, 115, 3-31.

Stow, D.A.V., Faugères, J.-C., Howe, J., Pudsey, C. and Viana, A. (2002) Bottom currents, contourites and deep-sea sediment drifts: current state-of-the-art. In: Deep-Water Contourite Systems: Modern Drifts and Ancient Series, Seismic and Sedimentary Characteristics (Eds D. Stow, C. Pudsey, J. Howe, J.-C. Faugères and A. Viana) Geological Society Memoirs, London, 7-20.

Stow, D.A.V., Hunter, S., Wilkinson, D. and Hernández-Molina, F.J. (2008) The nature of contourite deposition. In: Contourites (Eds M. Rebesco and A. Camerlenghi) Developments in Sedimentology, 60, 143-156.

Stow, D.A.V., Hernández-Molina, F.J., Llave, E., Sayago-Gil, M., Díaz del Río, V. and Branson, A. (2009) Bedform-velocity matrix: The estimation of bottom current velocity from bedform observations. Geology, 37, 327-330.

Stow, D.A.V., Brackenridge, R., Patel, U. and Toulmin, S. (2012) Geohazards and Ocean Hazards in Deepwater: Overview and methods of Assessment. Offshore Technology Conference. Houston, Abstract Volume 23697.

Stow, D.A.V., Hernández-Molina, F.J., Alvarez Zarikian, C. and the Expedition 339 Scientists. (2013a) Mediterranean Outflow: Environmental significance of the Mediterranean Outflow Water. Proc. IODP, 339. Tokyo, Integrated Ocean Drilling Program Management International, Inc.

Stow, D.A.V., Hernández-Molina, F.J., Llave, E., Bruno, M., García, M., Díaz del Rio, V., Somoza, L. and Brackenridge, R. (2013b) The Cadiz Contourite Channel: Sandy contourites, bedforms and dynamic current interaction. Marine Geology, 343, 99-114. 
Tasianas, A. (2010) Mud diapirism in the Gulf of Cadiz contourite depositional system: Study of the distribution, scale, size of these features and the effects on structural pattern and thickness of the contourite sediments around it. Unpublished M.Sc. Thesis, Heriot-Watt University, Edinburgh, Scotland, 64pp.

van der Schee, M., Sierro, F.J., Jiménez-Espejo, F.J., Hernández-Molina, F.J., Flecker, R., Flores, J.A., Acton, G., Gutjahr, M., Grunert, P., García-Gallardo, A. and Andersen, N. (2016) Evidence of early bottom current flow after the Messinian Salinity Crisis in the Gulf of Cadiz. Marine Geology, 380, 315-329.

Viana, A. (2008) Economic relevance of contourites. In: Contourites (Eds M. Rebesco and A. Camerlenghi) Developments in Sedimentology, 60, 493-510.

Viana, A., Faugères, J.-C. and Stow, D. (1998) Bottom-current-controlled sand deposits - a review of modern shallow- to deep-water environments. Sedimentary Geology, 115, 53-80.

Viana, A. and Rebesco, M. (2007) Economic and Palaeoceanographic Significance of Contourite Deposits. Geological Society, London, Special Publication 276, 350 pp.

Wentworth, C. (1922) A scale of grade and class terms for clastic sediments. Journal of Geology, 30, 377-392.

Wetzel, A., Werner, F. and Stow, D.A.V. (2008) Bioturbation and biogenic sedimentary structures in contourites. In: Contourites (Eds M. Rebesco and A. Camerlenghi) Developments in Sedimentology, 60, 183-202.

Youbin, H., Jinxiong, L., Xiangdong, L., Zhenzhong, G. and Zhan, W. (2011) Evidence of internal wave and internal-tide deposits in the Middle Ordovician Xujiajuan Formation of the Xiangshan Group, Ningxia, China. Geo-Marine Letters, 31, 509-523.

Youbin, H., Zhengzhong, G., Jinxiong, L., Shunshe, L. and Xuefeng, L. (2008) Characteristics of internal-wave and internal-tide deposits and their hydrocarbon potential. Petroleum Science, 5, 37-44. 
Zenk, W. (1975) On the Mediterranean outflow west of Gibraltar. Meteor Forschungsergeb, 16, 2334.

Zitellini, N., Gracia, E., Matias, L., Terrinha, P., Abreu, M., DeAlteriis, G., Henriet, J., Danobeitia, J., Masson, D., Mulder, T., Ramella, R., Somoza, L. and Diez, S. (2009) The quest for the Africa-Eurasia plate boundary west of the Strait of Gibraltar. Earth and Planetary Science Letters, 280, 13-50. 


\section{FIGURE CAPTIONS AND TABLES}

Table 1: The sediment cores used in the study of sediment facies sequences in the Gulf of Cadiz and their depositional environment. *In this study, logging was restricted to the uppermost $10 \mathrm{~m}$ of the Integrated Ocean Drilling Program (IODP) cores.

Table 2: Calibrated ${ }^{14} \mathrm{C}$ dates and errors acquired from four cores across the eastern Gulf of Cadiz. Dating completed at: (i) the SUERC Radiocarbon Facility, (University of Glasgow); and (ii) the Laboratoire de Mesure du Carbone 14 (Université Paris-Saclay).

Fig. 1. The Gulf of Cadiz and the main study area (red outline box). Key oceanographic components marked are the eastward-flowing Atlantic Inflow Waters (AIW) and the Mediterranean Outflow Water (MOW). Numbers relate to the Hernández-Molina et al. (2003) contourite depositional sectors: (1) proximal scour and sand ribbons sector; (2) overflow-sedimentary lobe sector; (3) channels and ridges sector; (4) active contourite drift sector; and (5) submarine canyons sector. Modified from Hernández-Molina et al. (2003) and Zitellini et al. (2009).

Fig. 2. Location of the recovered sediment cores in this study and their position in relation to morphosedimentary features defined by Hernández-Molina et al. (2014). Modified from Habgood et al. (2003) and Hernández-Molina et al. (2006, 2014).

Fig. 3. Lithological logs for the seven cores used in this study. Core photographs and CT images shown alongside the lithological logs where available. Samples taken for smear slide analysis, grainsize measurement and ${ }^{14} \mathrm{C}$ dating are indicated.

Fig. 4. Sorting plot with average grain-size curve. Measurements were made at a $2 \mathrm{~cm}$ resolution except for core U1388 where samples are indicated as points. Some sections show increasing sorting with increasing grain size, whereas others show decreasing sorting with increasing grain size.

Figure 5: (A) Cross-plot of sorting against mean grain-size reveals that mud and fine silt has a negative relationship with sorting and medium silt to fine sand has a positive association with sorting. Medium to coarse sands return to poorer sorting. (B) Mean grain size versus skewness. Finest grain sizes show a minor coarse tail or near-normal distribution. Sands show a coarse skew. (C) Mean grain 
size versus kurtosis. Fine sands show a higher concentration of grain sizes around the mean whereas the finer silts and coarser sands show a broader (platykurtic) spread.

Figure 6: (A) Sorting versus skewness cross-plot showing multiple trends. Data points are colourcoded with respect to mean grain size, and there appears to be a direct link between cross-plot trends and mean grain size. (B) Kurtosis versus skewness cross-plot showing multiple trends. Data points are colour coded with respect to mean grain size.

Fig. 7. Cumulative frequency curves for each mean grain-size division. The curves show an important change in the dominant transport process between fine silt and very coarse sand, as represented by a change in the trend of the curve.

Fig. 8. Age-depth plots and accumulation rates for the dated sediment cores. The anomalous date at about $3 \mathrm{~m}$ depth in the very sand-rich core U1388 is probably due to an especially high level of sediment re-working at the sea floor.

Fig. 9. Facies observed across the seven sediment cores in the Gulf of Cadiz with assigned contourite divisions C1 to C5 after Stow \& Faugères (2008). Localities are indicated on Fig. 2. The standard contourite sequence is also shown (modified from Gonthier et al., 1984; Stow \& Faugères, 2008). Locations of core photographs in Fig. 10 are indicated.

Fig. 10: Contourite facies observed across the eastern Gulf of Cadiz. (A) to (C) Displayed as core photographs (left) and CT scan (right). (A) Facies A - bioturbated muddy facies; PC08, 0.5 mbsf. (B) Facies B - mottled silty contourite facies; PC04, 2.7 mbsf. (C) Facies C - very fine sandy mottled to fine-grained sandy bioturbated facies; PC06, 0.4 mbsf. (D) Facies D - massive (left) or laminated (right, boxed) medium-grained sandy contourite facies; U1388, 0.94 mbsf; U1388, 5.2 mbsf. (E) Facies E - coarse-grained sandy and gravel facies; $\mathrm{BC} 05,0 \mathrm{~cm}$. 
Fig. 11. A cross-plot of sorting against mean grain size reveals that the finest sediments have a negative relationship with sorting and medium silt to fine-grained sand has a positive association with sorting. Medium to coarse sands return to poorer sorting. Sorting definitions given by Folk (1964).

Figure 12: Sorting versus skewness cross-plot showing multiple trends. Data points are colour coded with respect to mean grain size, and there appears to be a link between cross-plot trends and mean grain size. Grain-size distribution curves for each of the highlighted areas of the graph. Skew changes in response to grain size. See text for explanation.

Fig. 13. Contourite sand facies and key characteristics.

Fig. 14. End-member models of grain-size distribution as expected for each depositional process acting in deep water. In reality, there is a continuum between processes; and mixed systems may occur. Distribution is also strongly controlled by sediment provenance. 


\begin{tabular}{|l|l|l|l|l|l|l|l|}
\hline Cruise & Core & $\begin{array}{l}\text { Latitude } \\
(\mathrm{\circ})\end{array}$ & $\begin{array}{l}\text { Longitude } \\
\left({ }^{\circ} \mathrm{E}\right)\end{array}$ & $\begin{array}{l}\text { Water depth } \\
(\mathrm{m})\end{array}$ & $\begin{array}{l}\text { lore length* } \\
(\mathrm{m})\end{array}$ & $\begin{array}{l}\text { Contourite deposit type (from } \\
\text { Hernández-Molina et al (2014) }\end{array}$ & \begin{tabular}{l} 
\# Grain-size samples \\
\hline CONTOURIBER
\end{tabular} \\
\hline BC05 & 35.845 & -6.780 & 738 & 0.23 & Contourite channel & 23 \\
\hline CONTOURIBER & PC04 & 35.736 & -6.732 & 658 & 6.22 & Mounded drift & 286 \\
\hline CONTOURIBER & PC04 TG & 35.736 & -6.732 & 658 & 1.00 & Mounded drift & 39 \\
\hline CONTOURIBER & PC08 & 35.821 & -6.968 & 961 & 5.36 & Mounded drift & 252 \\
\hline CONTOURIBER & PC08 TG & 35.821 & -6.968 & 961 & 1.00 & Mounded drift & 48 \\
\hline IODP 339 & U1388 & 36.161 & -6.476 & 663 & $121.00^{*}$ & Contourite channel & 33 \\
\hline
\end{tabular}




\begin{tabular}{|c|c|c|c|c|c|c|c|}
\hline Core & Sample mbsf & ${ }^{14} \mathrm{C}$ age (BP) & Error \pm & Age cal BP & Error \pm & Laboratory & Material \\
\hline \multirow{3}{*}{ PC06 } & 0.36 & 5525 & 28 & 5917 & 71 & SUERC & Mixed planktonic \\
\hline & 1.52 & 9585 & 29 & 10455 & 87 & SUERC & Mixed planktonic \\
\hline & 2.24 & 10645 & 35 & 11968 & 142 & SUERC & Mixed planktonic \\
\hline \multirow{3}{*}{ U1388 } & 0.08 & 8390 & 40 & 8983 & 138 & Lab. Mesure $\mathrm{du}^{14} \mathrm{C}$ & Mixed planktonic \\
\hline & 3.08 & 7990 & 45 & 8455 & 97 & Lab. Mesure du ${ }^{14} \mathrm{C}$ & Mixed planktonic \\
\hline & 4.76 & 42220 & 950 & 45449 & 1916 & Lab. Mesure $\mathrm{du}{ }^{14} \mathrm{C}$ & Mixed planktonic \\
\hline \multirow{4}{*}{ PCO4 } & 0.04 & 11292 & 30 & 12768 & 134 & SUERC & Mixed planktonic \\
\hline & 3.56 & 34279 & 183 & 38910 & 514 & SUERC & Mixed planktonic \\
\hline & 4.38 & 35212 & 196 & 39836 & 765 & SUERC & Mixed planktonic \\
\hline & 5.64 & 35750 & 470 & 39960 & 1075 & Lab. Mesure $d u{ }^{14} \mathrm{C}$ & Mixed planktonic \\
\hline \multirow{3}{*}{ PC08 } & 0.04 & 4973 & 28 & 5346 & 85 & SUERC & Mixed planktonic \\
\hline & 2.60 & 39032 & 305 & 42949 & 555 & SUERC & Mixed planktonic \\
\hline & 5.04 & 45900 & 1400 & 47983 & 1400 & Lab. Mesure $\mathrm{du}{ }^{14} \mathrm{C}$ & Mixed planktonic \\
\hline
\end{tabular}




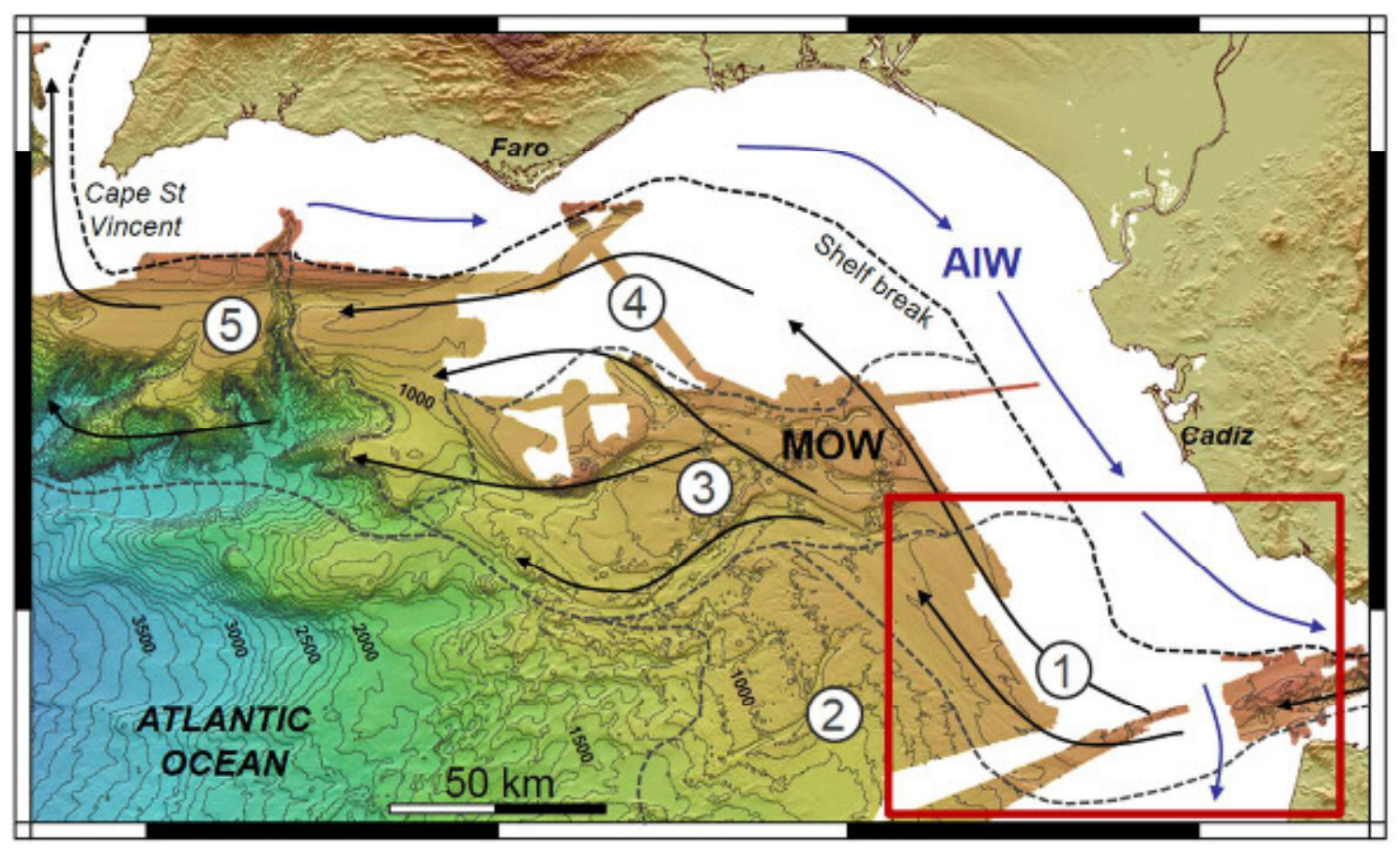

This article is protected by copyright. All rights reserved. 


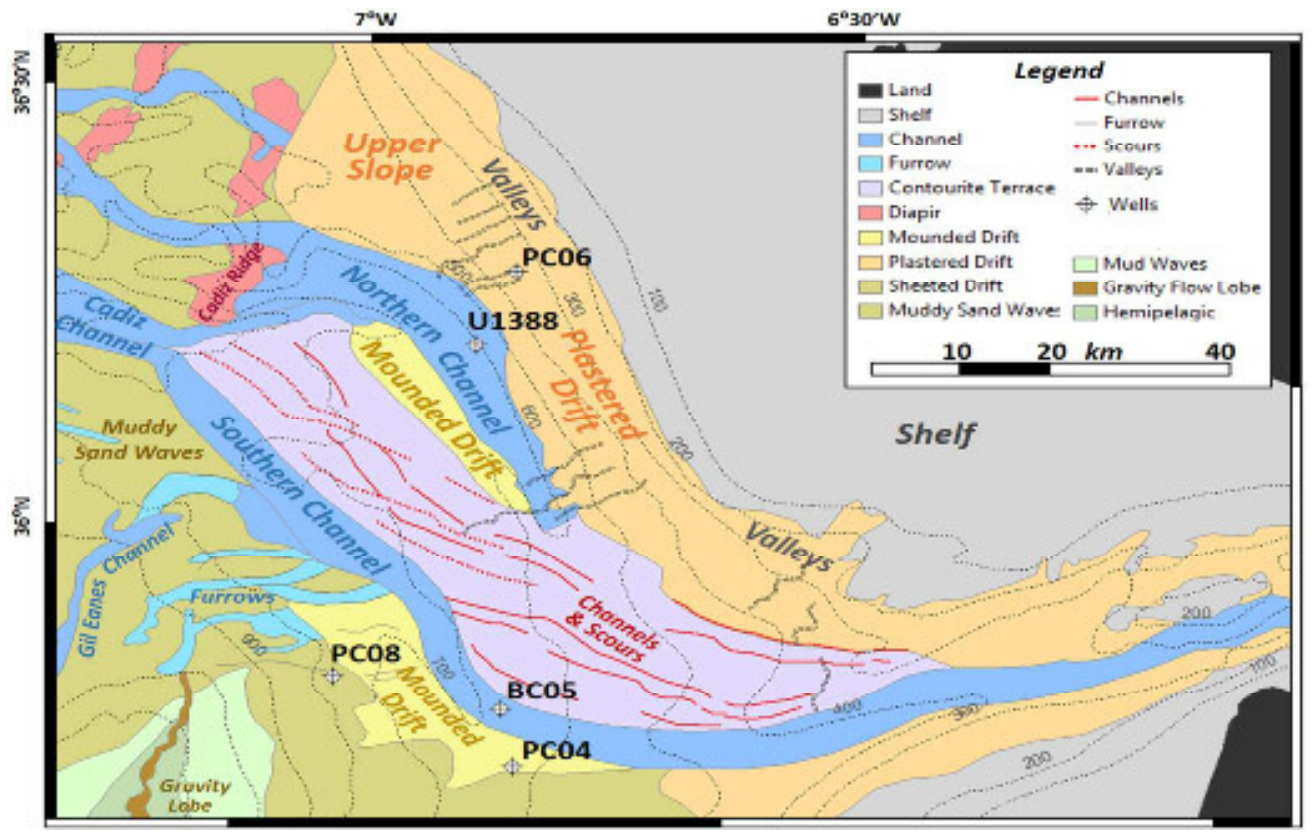

This article is protected by copyright. All rights reserved. 


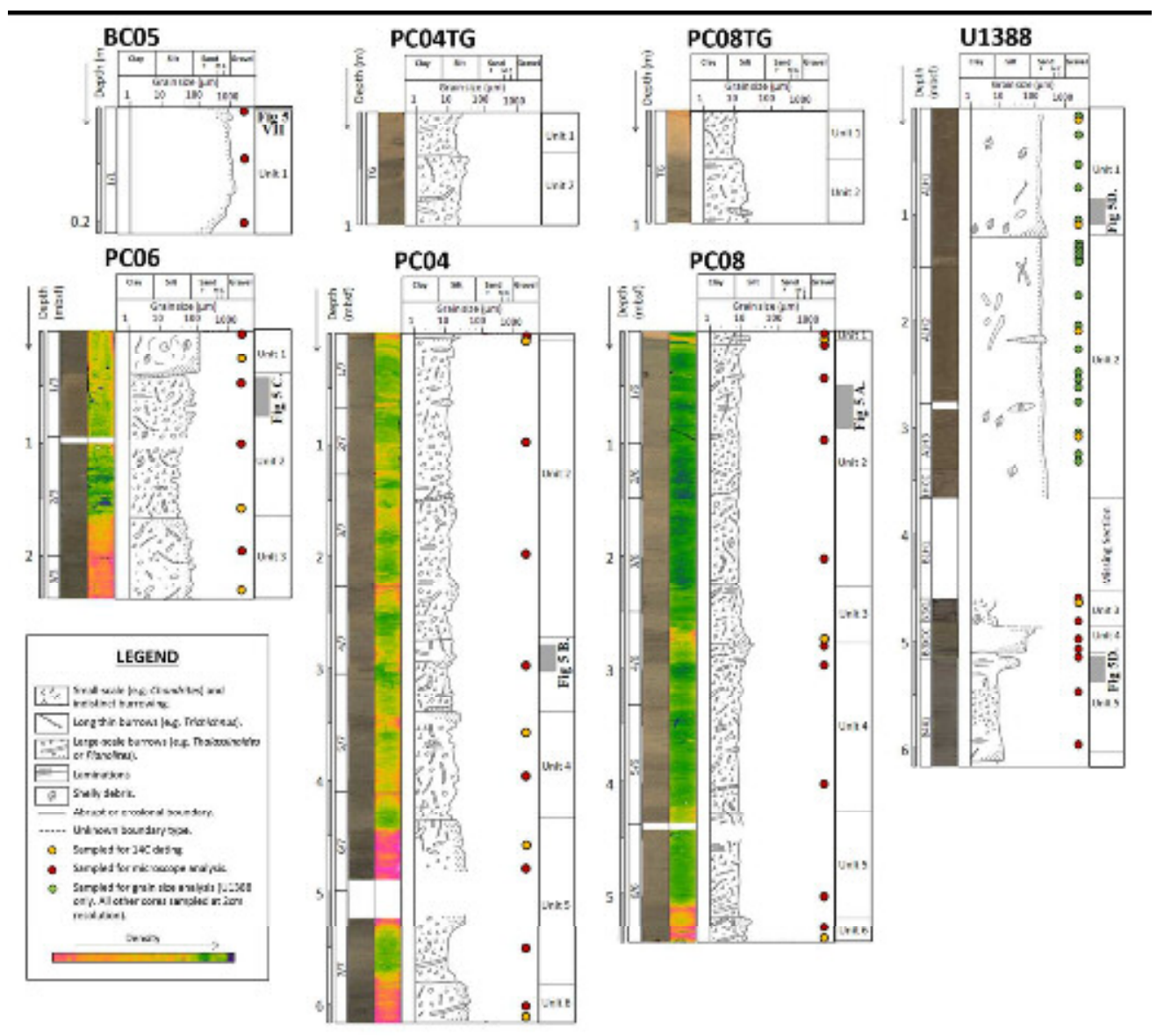




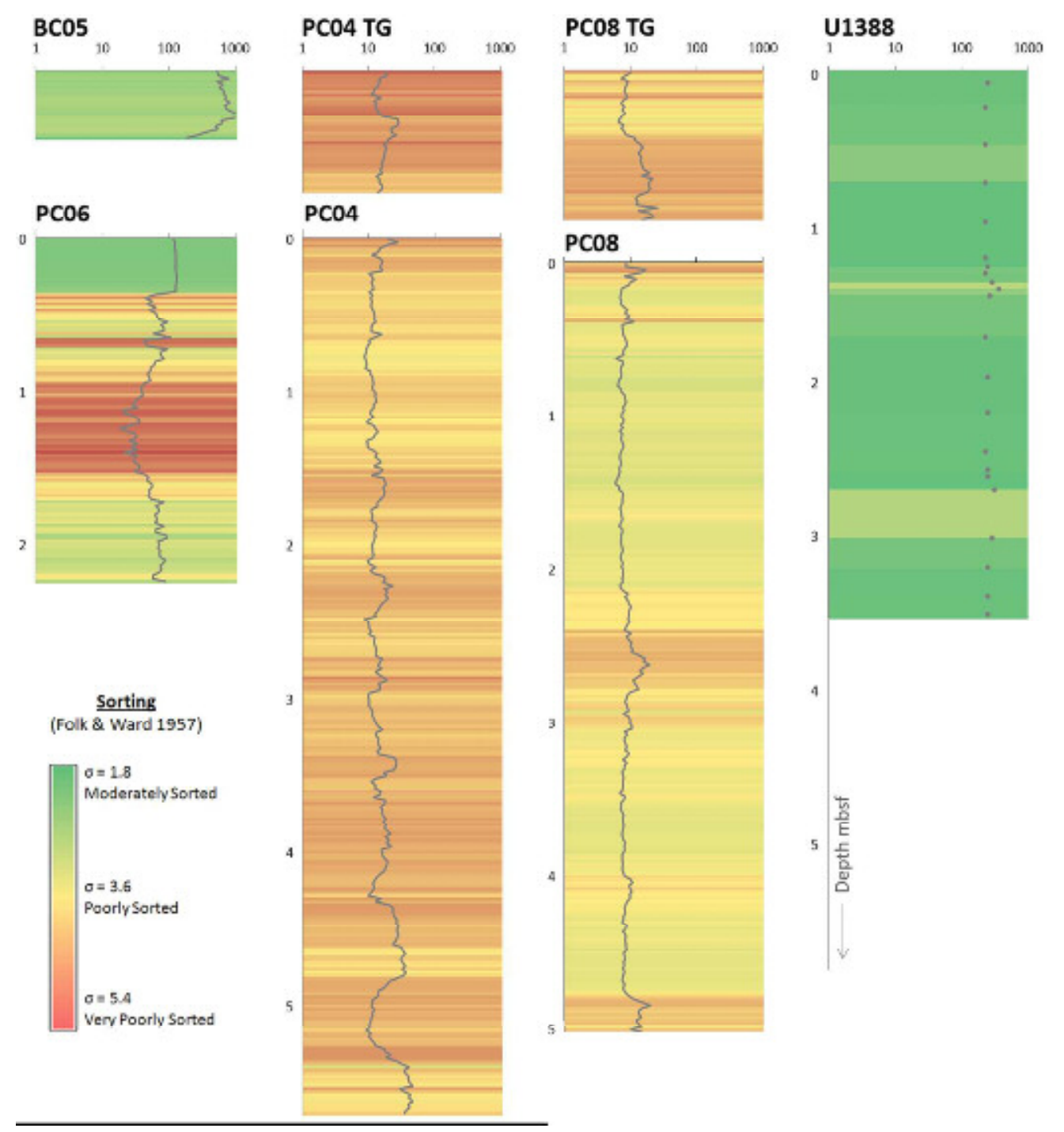



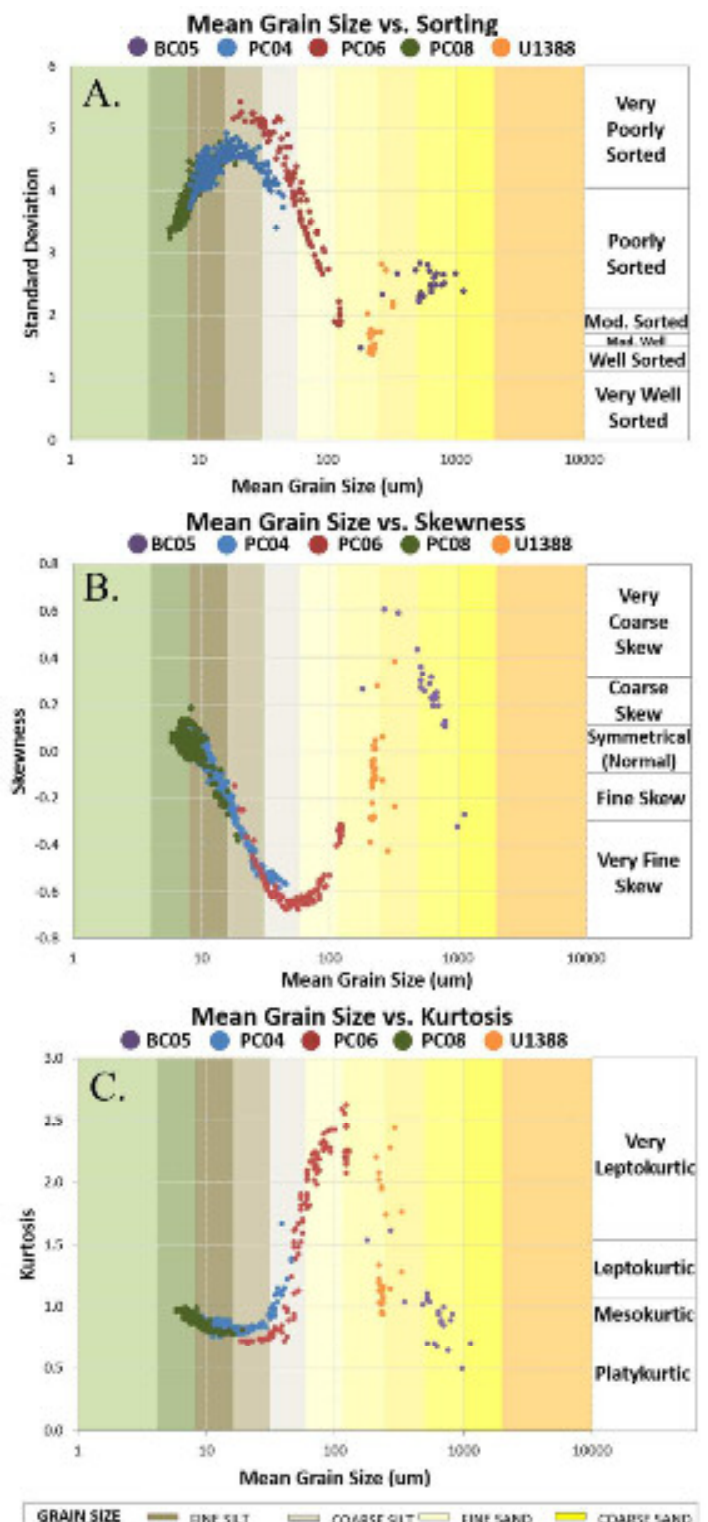

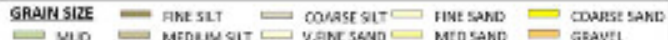



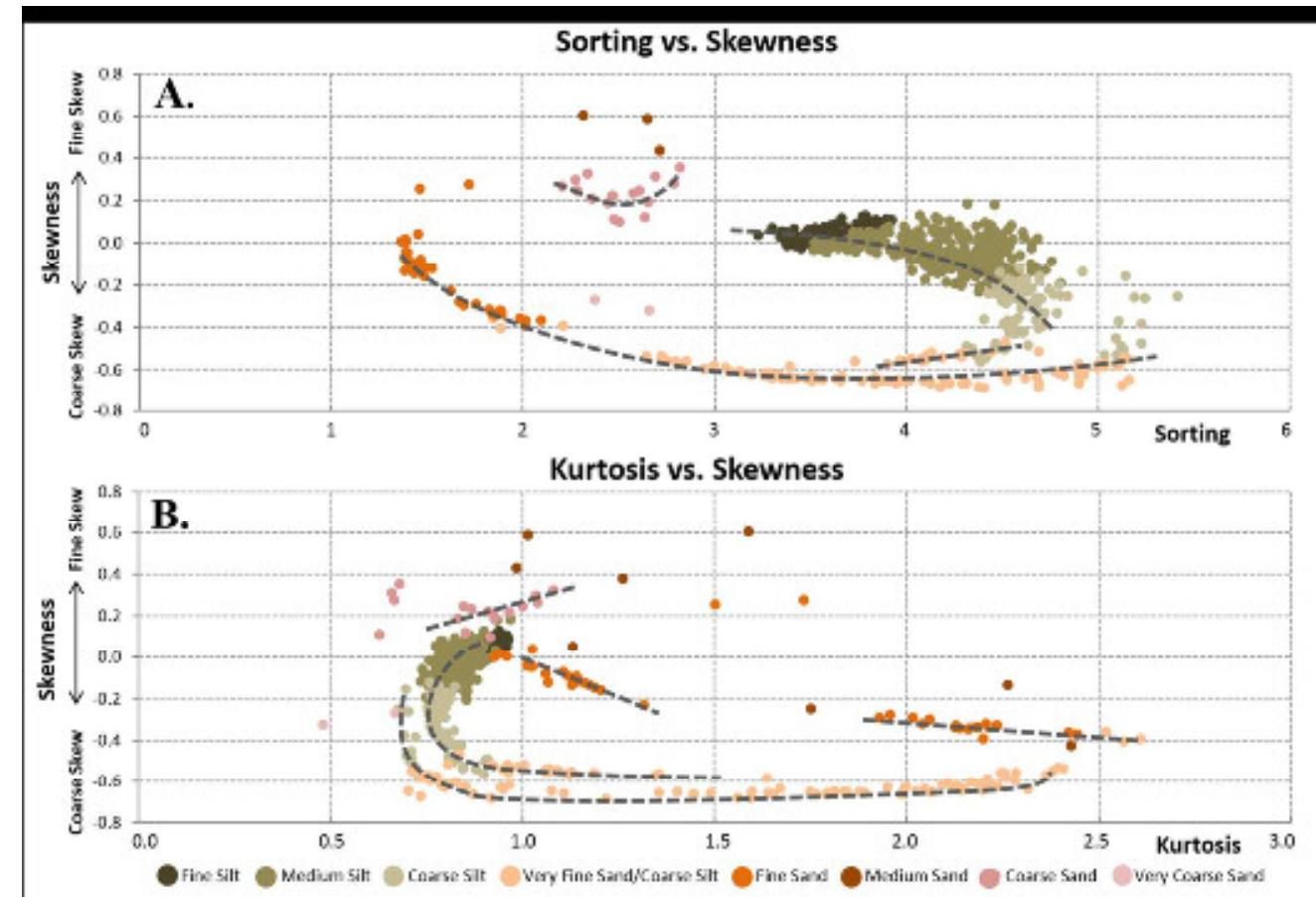

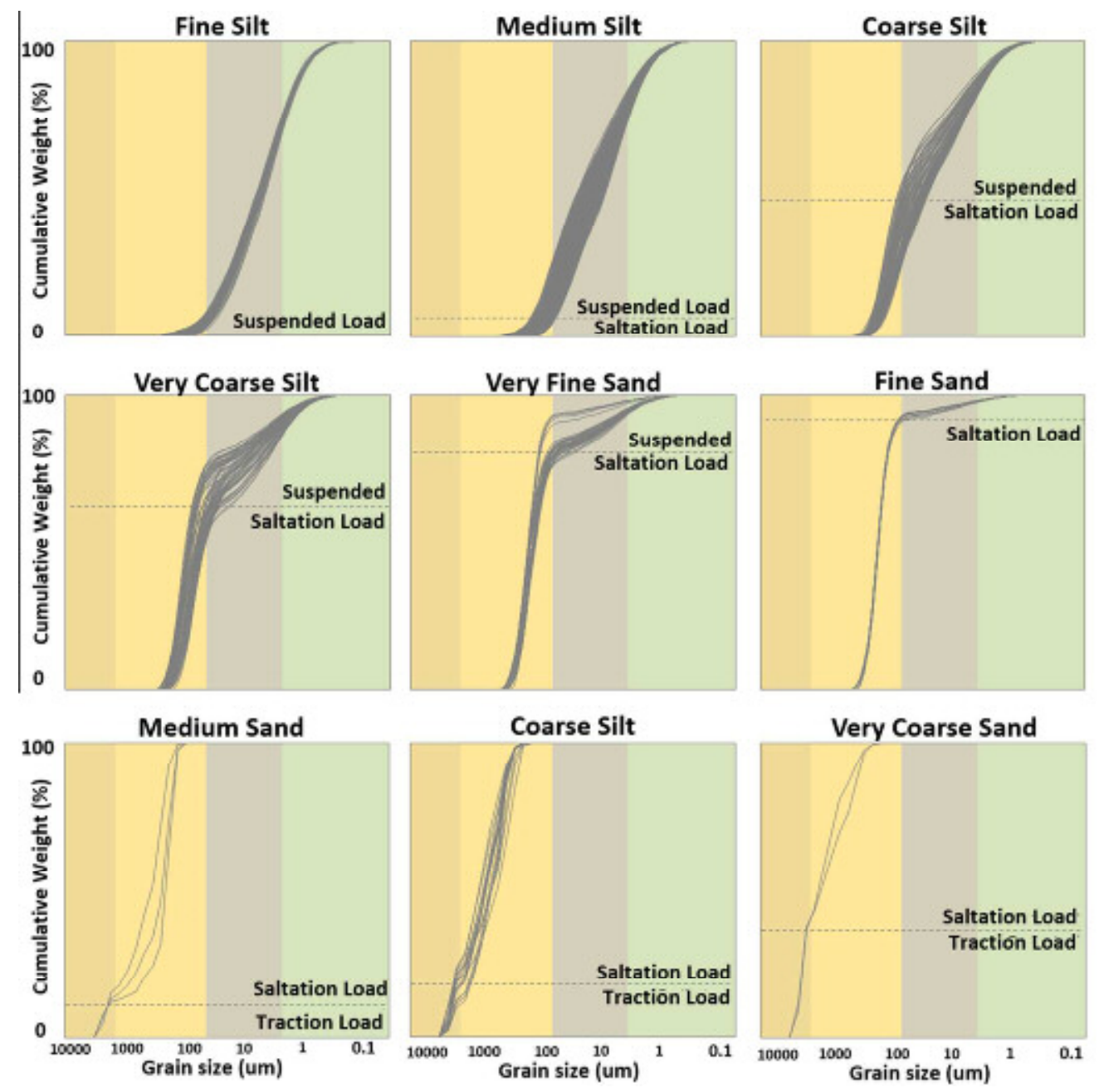

This article is protected by copyright. All rights reserved. 

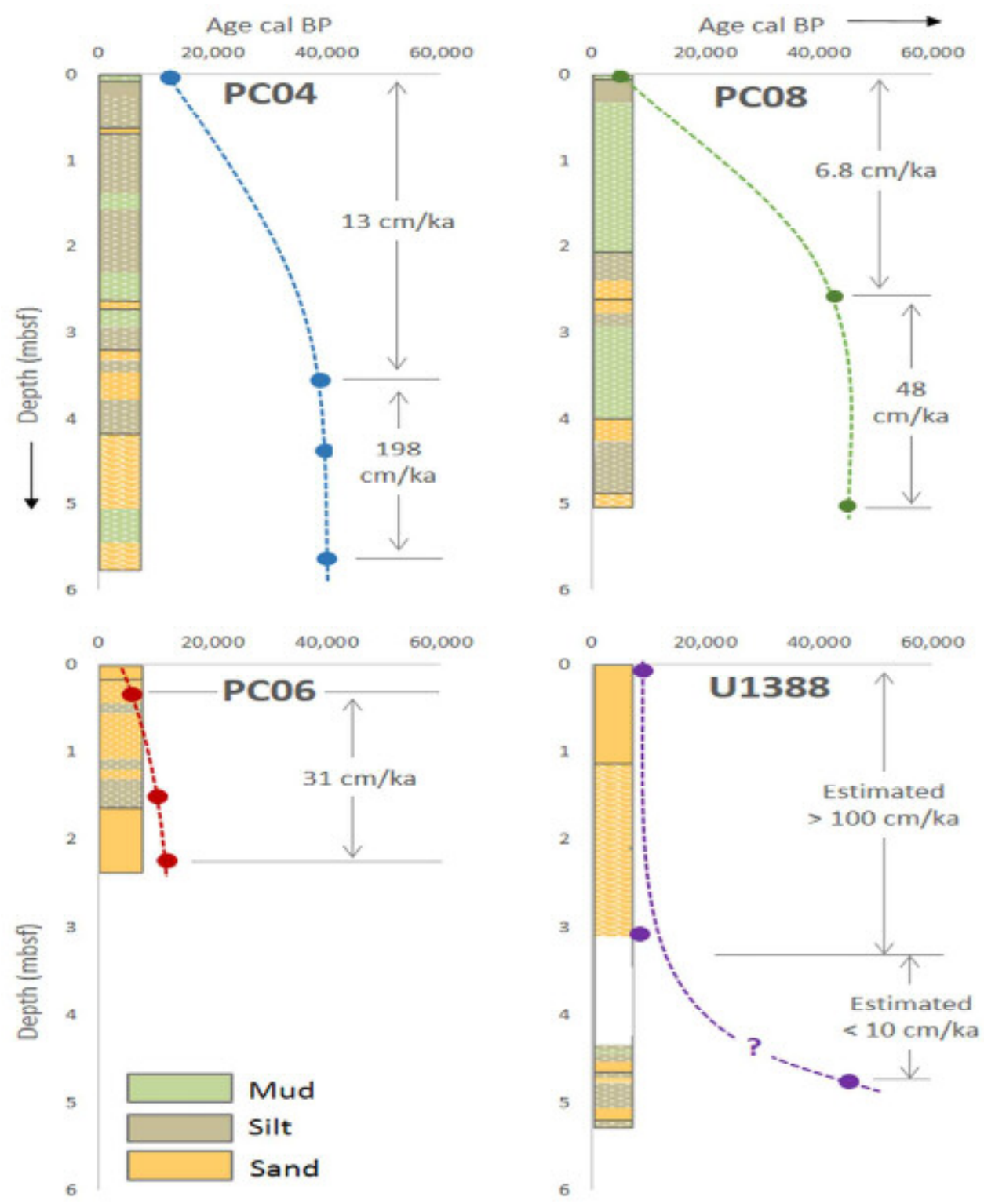


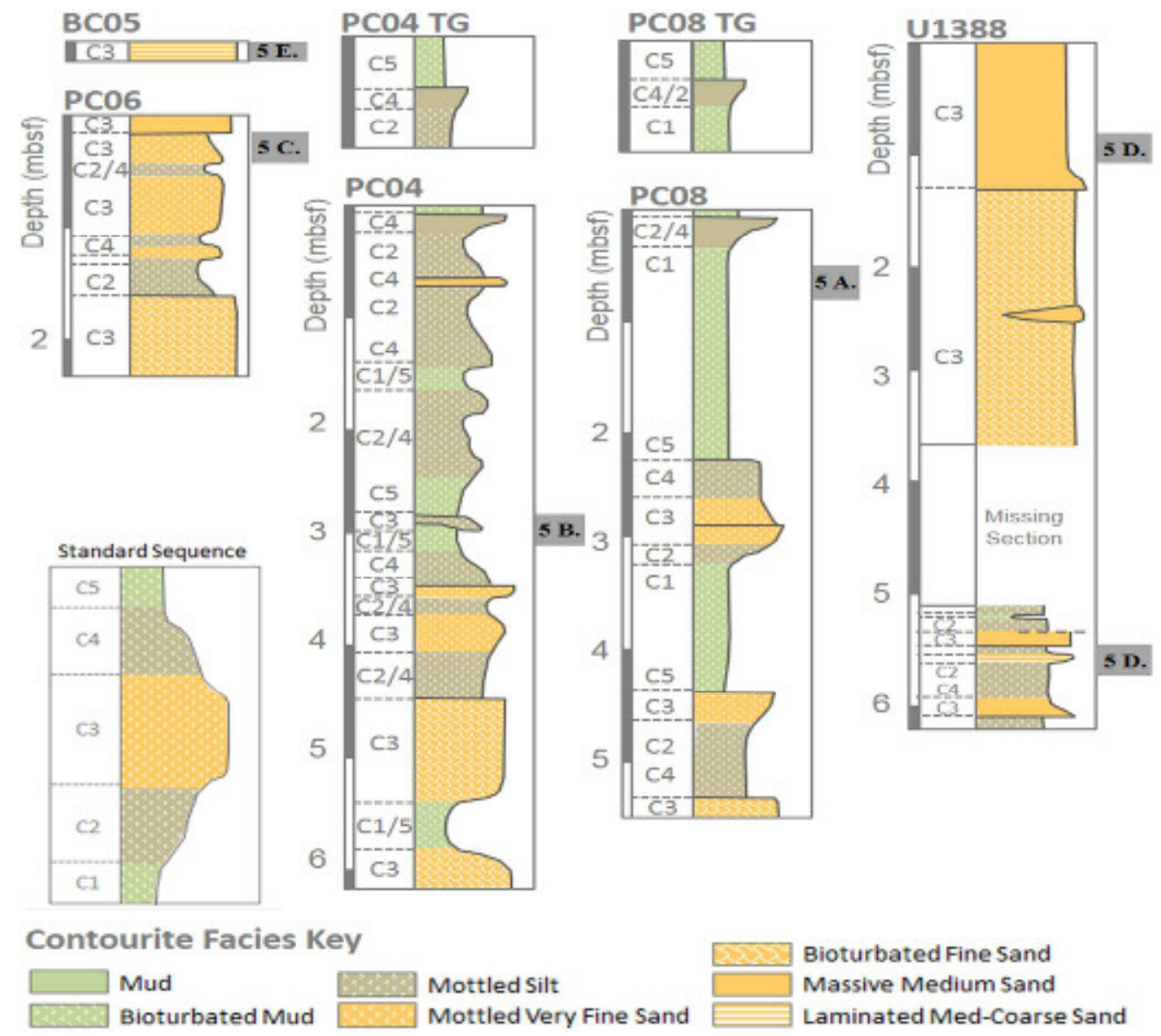



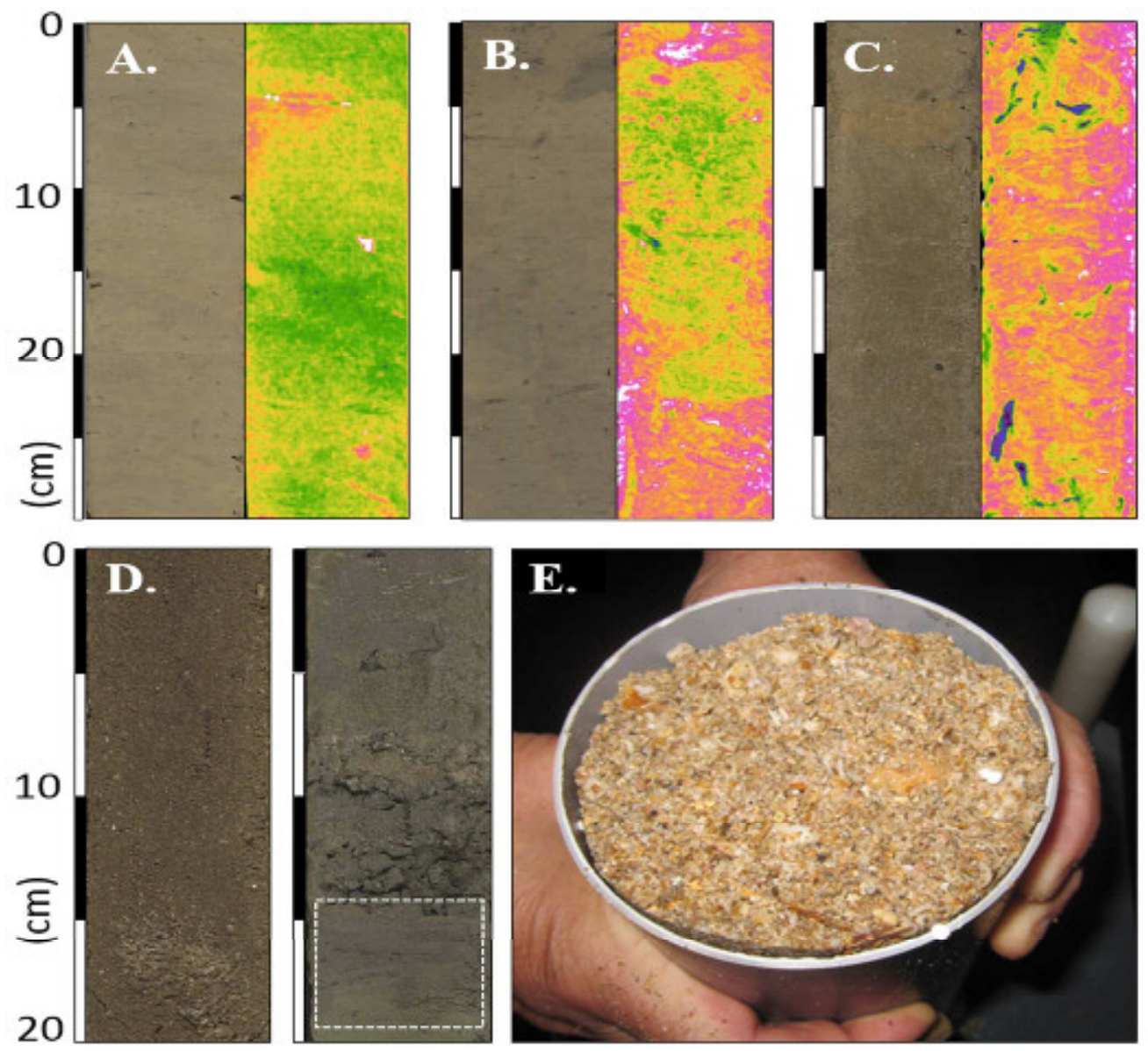


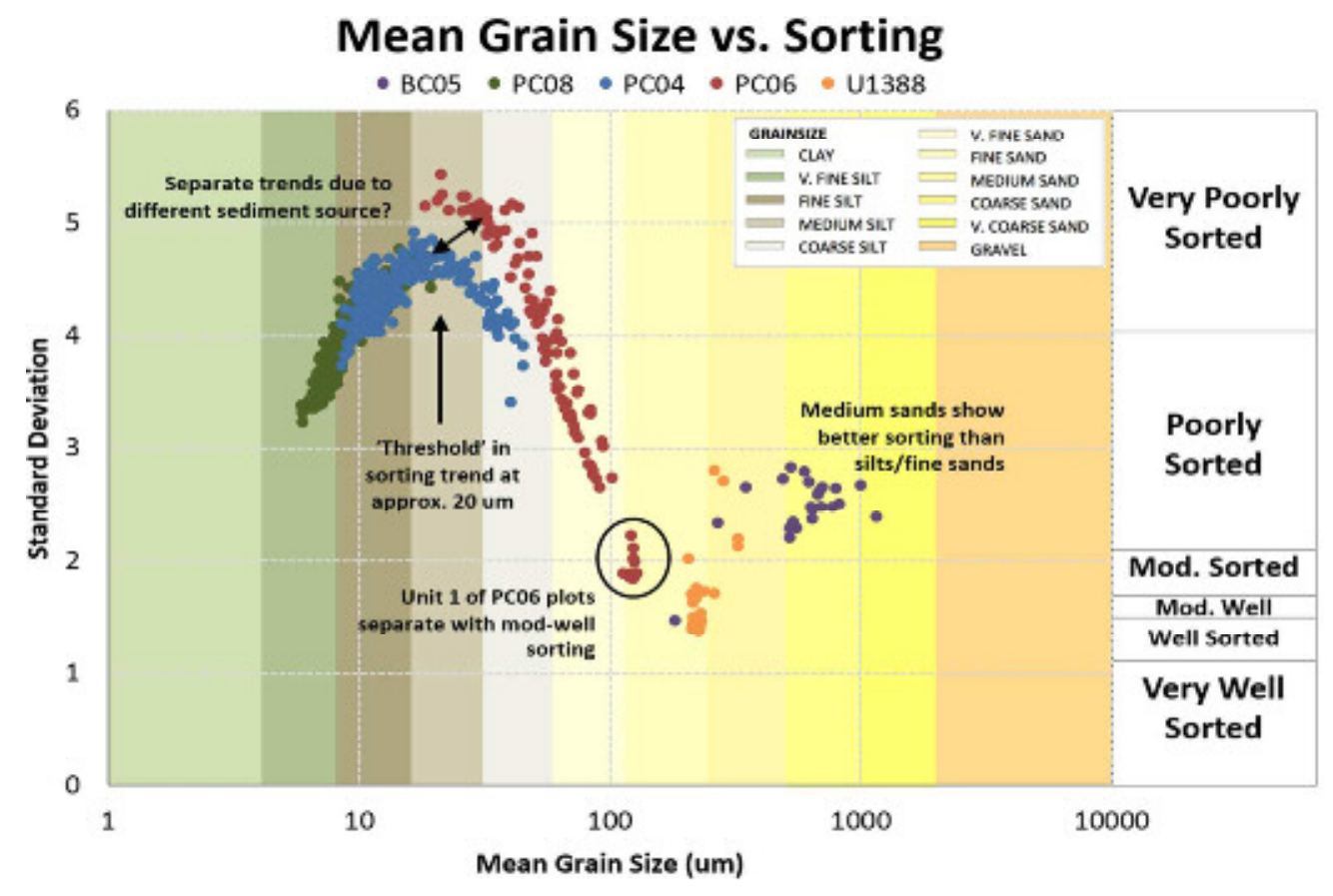

This article is protected by copyright. All rights reserved. 


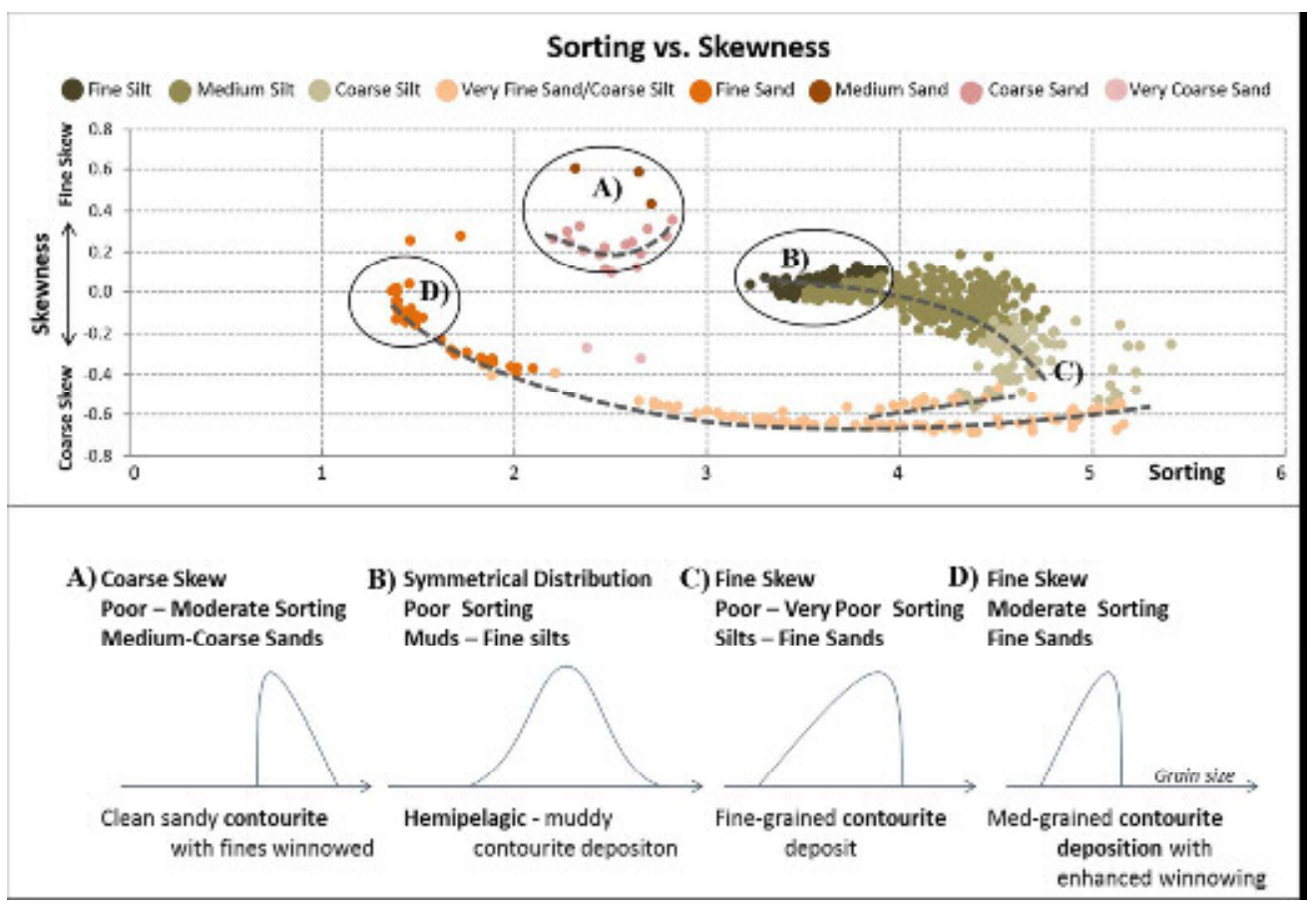

This article is protected by copyright. All rights reserved. 


\begin{tabular}{|l|l|l|}
\hline C1 & Standard Contourite Facies Model \\
\hline C2 & $\begin{array}{l}\text { Facies: Very fine grained sand, heavily bioturbated and } \\
\text { mottled in appearance. Bi-gradational grading to } \\
\text { extensively bioturbated silts and muds. }\end{array}$ \\
\hline C3 & $\begin{array}{l}\text { Ichnofacies: Very highly bioturbated with a mottled } \\
\text { appearance. Larger (cm-scale) burrows also common. } \\
\text { Sorting: Very poor } \\
\text { Skew: Fine } \\
\text { GDE: Contourite mounded drifts }\end{array}$ \\
\hline C5 & & \\
\hline
\end{tabular}

\begin{tabular}{|l|l|l|}
\hline & \multicolumn{1}{c|}{ Fine to Medium Grained Sandy Contourites } \\
Facies: Fine grained bioturbated to massive medium \\
grained sands. Omission or erosional surfaces common. \\
Some indications of grading, often associated with \\
erosional surfaces. \\
Ichnofacies: Reducing levels of bioturbation with \\
increasing grainsize. Large-scale burrows. \\
Sorting: Moderate \\
Skew: Fine to coarse \\
GDE: Contourite plastered drifts
\end{tabular}

\begin{tabular}{|l|l|l|}
\hline & $\begin{array}{l}\text { Coarse Grained Sandy and Gravel Lag Contourites } \\
\text { Facies: Medium to very coarse sands with gravel lags. } \\
\text { Can be laminated. Erosional scours and surfaces } \\
\text { common. Large bioclastic component common. }\end{array}$ \\
$\begin{array}{l}\text { Ichnofacies: No evidence of bioturbation } \\
\text { Sorting: Moderate to poor } \\
\text { Skew: Coarse to very coarse } \\
\text { GDE: Contourite channels }\end{array}$ \\
\hline
\end{tabular}




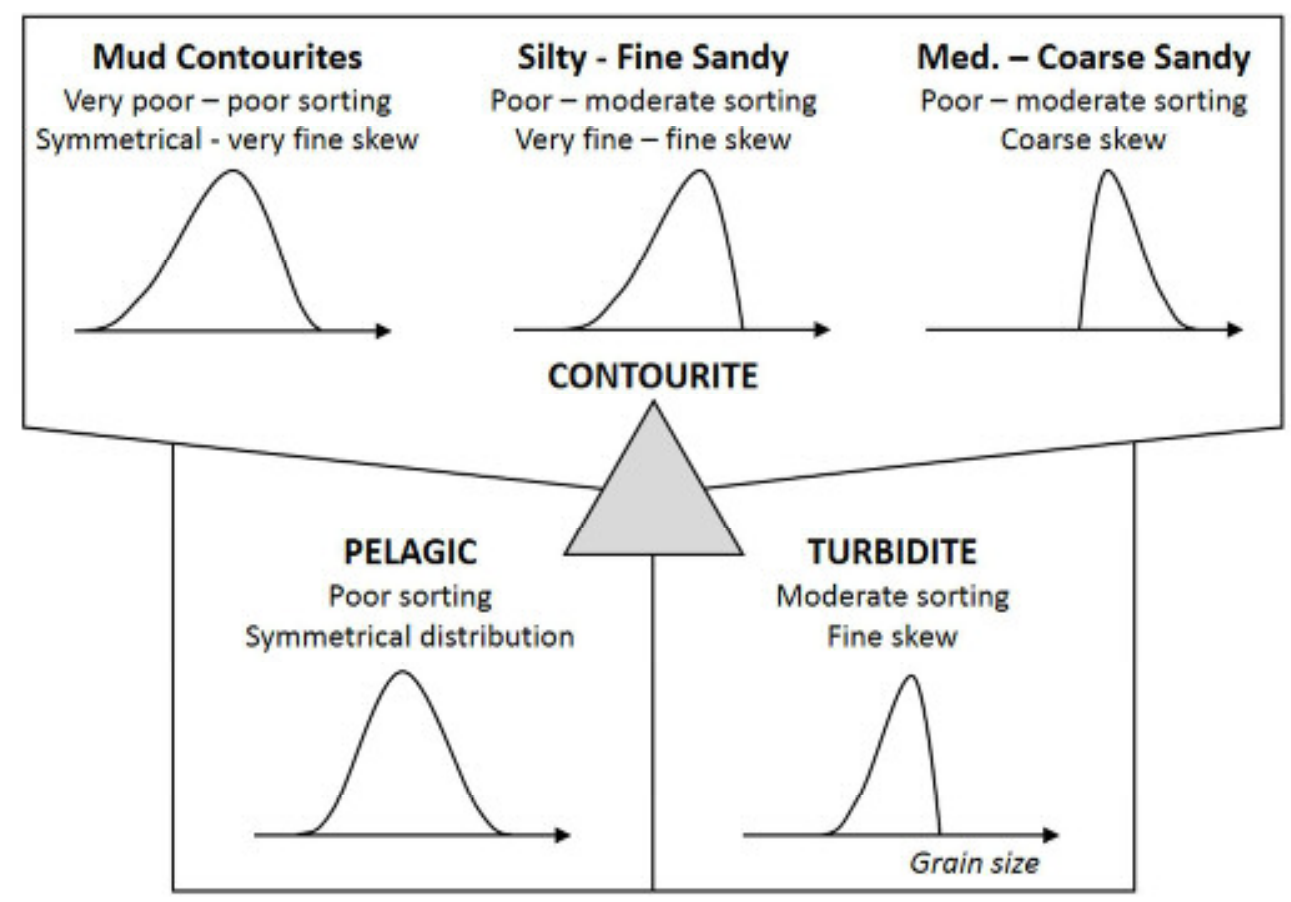

This article is protected by copyright. All rights reserved. 